
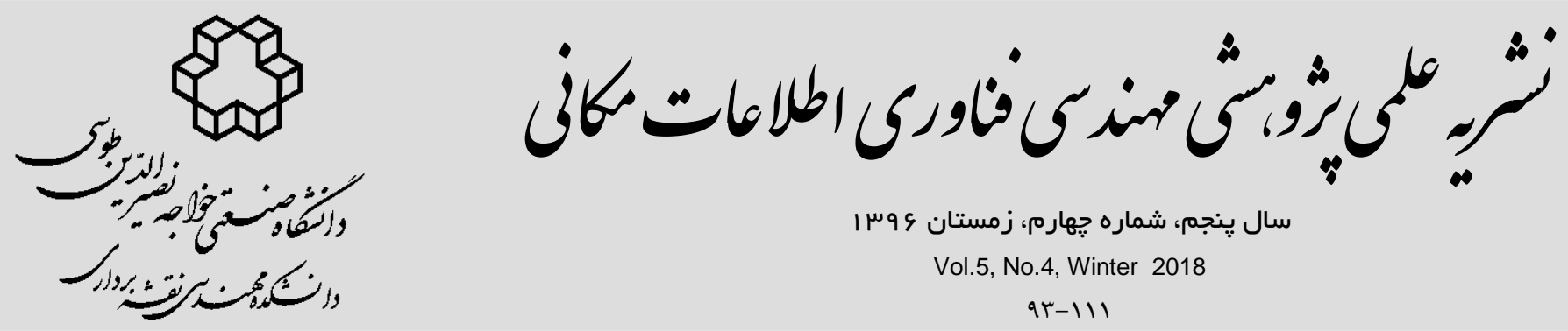

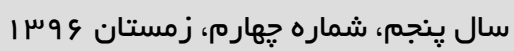

Vol.5, No.4, Winter 2018

$9 r-111$

مدلسازى و ييشبينى رشد افقى شهر مشهرد با استفاده از تلفيق اتوماتاى سلولى فازى، شبكه عصبى و رگرسيون لجستيك

فرهاد رستمى كله'، مرجان قائمى'، روزبه شاد "r"، ياسمن لهرابى"

ا - دانش آموخته كارشناسى ارشد عمران، سيستم اطلاعات مكانى دانشعاه فردوسى مشهد

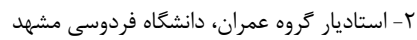

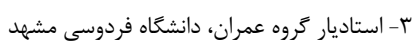

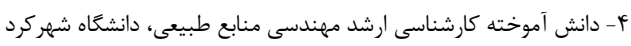

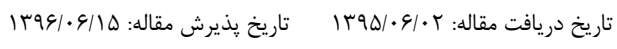

جكيده

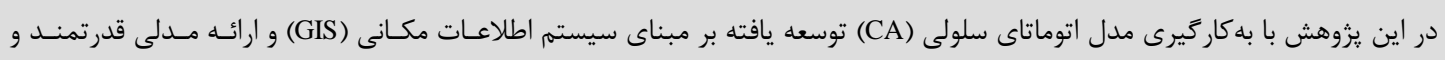

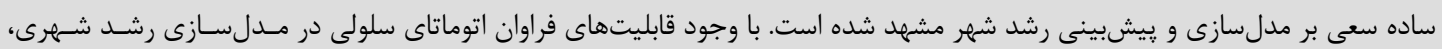

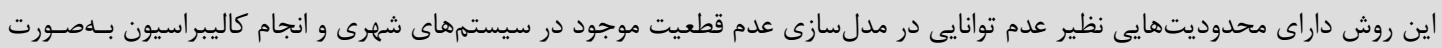

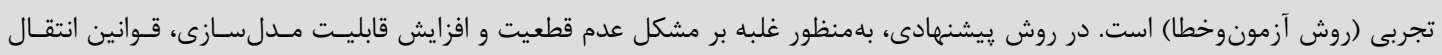

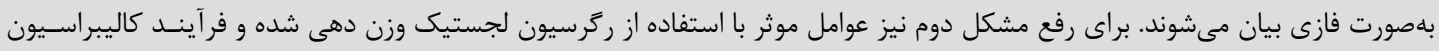

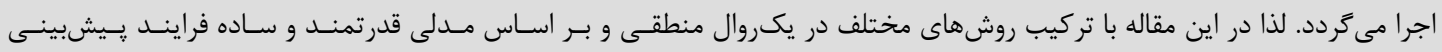

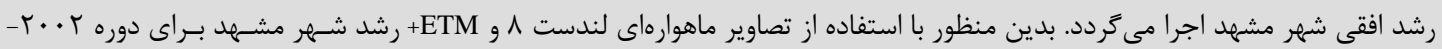

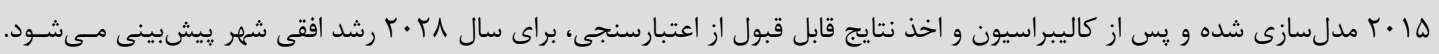

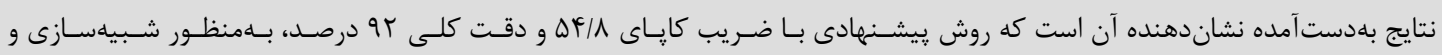

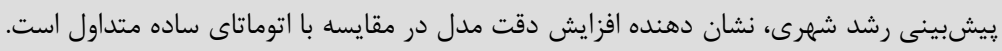

كليدوازهها: اتوماتاى سلولى فازى، يِشبينى رشد شهرى، سيستم اطلاعات مكانى، ركرسيون لجستيك، شبكه عصبى يرسيترون جندلايه. 
بنابراين مدلهاى مكانى توسعه شهرى بلعنوان ابزارى

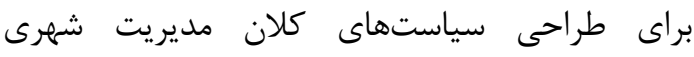

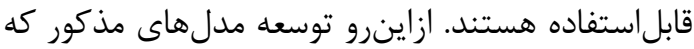
به קيامدهاى آينده رشد شهرى و طرحها و سياستهاى

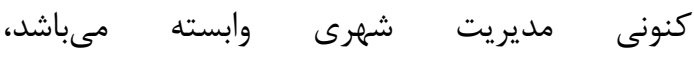

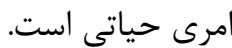

ازآنجايى كه شهرها از يِيجيدهترين سيستمهاى مكانى

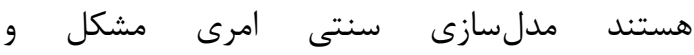

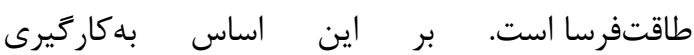
الكَوريتم اتوماتاى سلولى 'CA) در سيستمهاى شهرى ابزارى كارآمد مىباشد. علت اصلى اين موضوع مواردى إنى مانند سادكى محاسبات، نمايش واضح زمان- مكان و وارئ قابليت ارائه شبيهسازى واقعى از رشد شهرها هانيات هستند

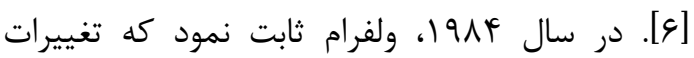
يديدهاى طبيعى به كمك اتوماتاى سلولى قابلنمايش مىباشند [V]]. مدل اتوماتاى سلولى بهدليل ساختار

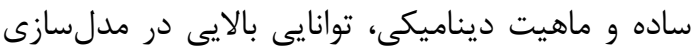

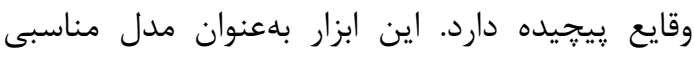

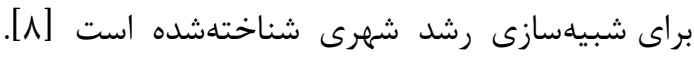
توبلر براى اولين بار از اين روش براى مدلسازى رساى رشد

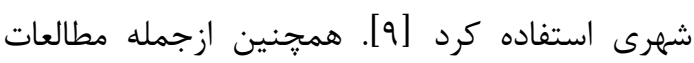
صورت كرفته در زمينهى شبيهسازى شهرى مى توان بهاده تحقيق وو [•[1]، لى و همكاران [1/]]، الخدر و همكاران

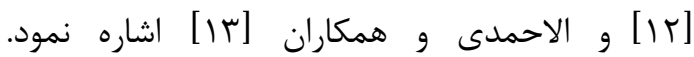

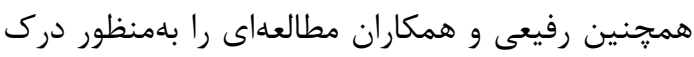
روابط يويا ميان عناصر شهرى، پيشبينى رشد ير يراكنده

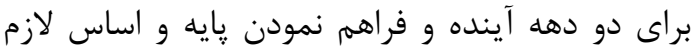
براى مديريت صحيح شهرى انجام دادند. محققين

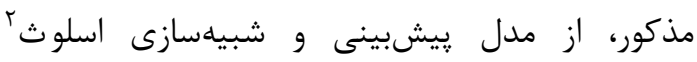

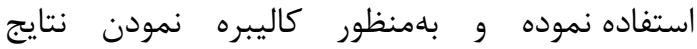

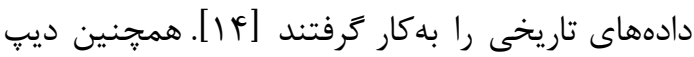

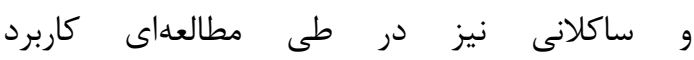

${ }^{1}$ Cellular Automata

${ }^{2}$ SLEUTH

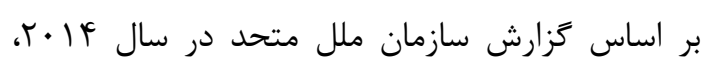

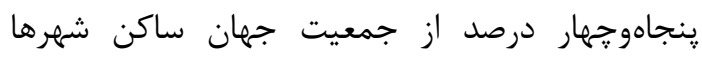

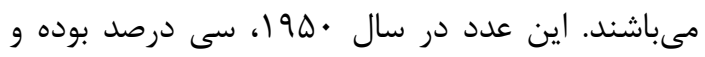

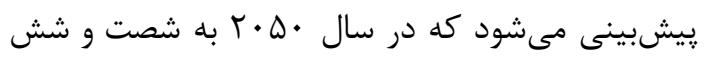
درصد (افزايش از ب/ ع ميليارد نفر به V/F ميليارد) برسد

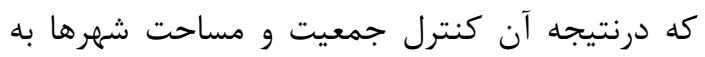

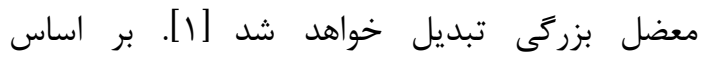
كزارش مذكور، سرعت شهرنشينى در آفريقا و آسيا

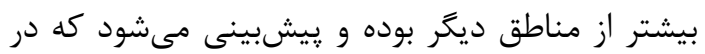

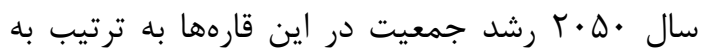
ميزان \&ه و وع درصد افزايش يابد [1]]. در ايران نيز

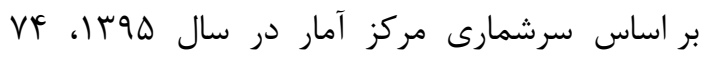

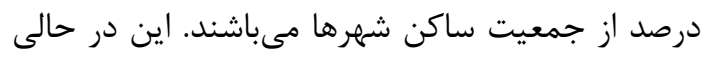

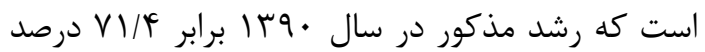
بوده و جمعيت شهرنشينى در سال هوبا نسبت به

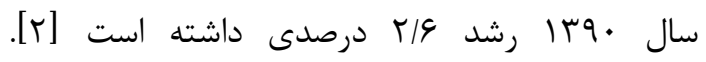

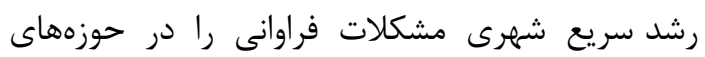
زيستمحيطى، اقتصادى، اجتماعى- فرهنكى و نظير

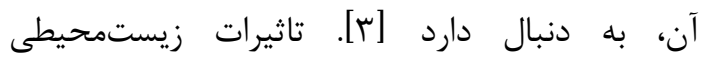

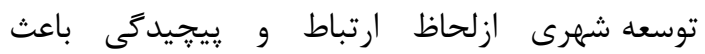
عدم توازن در كاربرى زمينهاى شهرى مئشئدئ. همجنين، با افزايش جمعيت و مساحت شهرى، سرانه

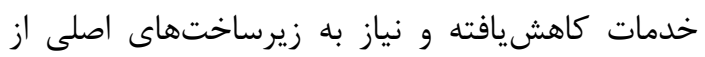
قبيل شبكه آب، برق، كاز و سرانه كاربرىهاى آموزشى نيى

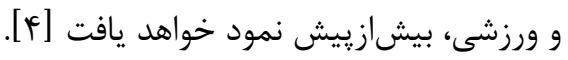
بنابر اين بهمنظور دستيابى به يك برنامه جامع، طراحان

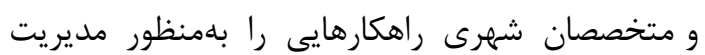

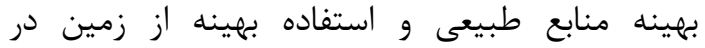
شهر هاى ايران ارائه مىنمايند. دو عامل اصلى، طراحان و برنامهريزان را دررسيدن هرجه بهتر به اهداف مافشان

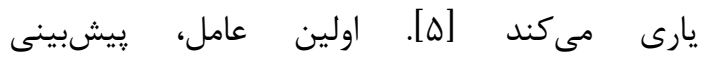
وضعيت كاربرى اراضى در آينده و دومين عامل، امكان إنين

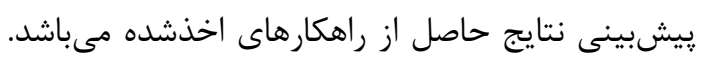


نتايج خواهد نمود. مشكل عمده در مدلسازى سيستمهاى يِيجيده با اتوماتاى سلولى آن

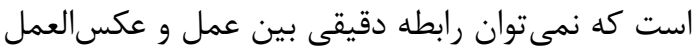
رفتارهاى طبيعى تعريف نمود. زيرا تعريف دقيق رفتار

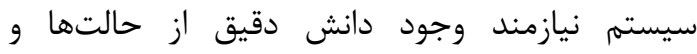

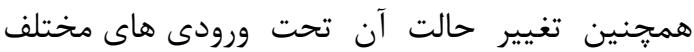

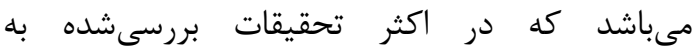
اين موضوع توجه نشده است. براى رفع اين مشكل بايد با استفاده از منطق فازى كميتهاى غيردقيق و مبهـهـ كه در تصميمگيرى درباره قوانين انتقال و تغيير حالتهاى سيستمم موثرند را تعريف نمود. از طرفى ديخر هدف از كاليبره كردن مدل، توليد مقادير وزنى بهينه مربوط به متغيرهاى ورودى است. لذا استفاده از روشهاى آمارى ازجمله ركرسيون لجستيك برخلاف

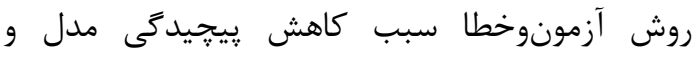

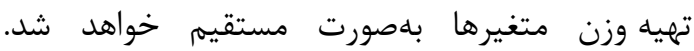
درنتيجه با توجه به موارد عنوانشده و با تركيب روشهاى مختلف در يك,روال منطقى، مدلى قدرتمند و

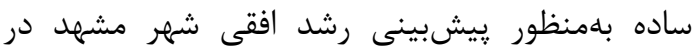
اين :ثروهش بيشنهاد مى گرىدد.

بنابراين در اين يزوهش ابتدا با نخرشى جز به كل،

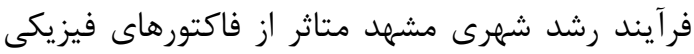
(دسترسى به خطوط مواصلاتى شهر، دسترسى به ايستخاههاى اتوبوس، دسترسى به ايستخاههاى مترو، اثر شيب، فاصله از مراكز تجارى اصلى شهر) و و فاكتورهاى انسانى (تسهيلات دولتى و ميزان تقاضاى زمين) در نظر كرفته مىشود. سيس، تصاوير موردنياز در محدوده مطالعاتى با استفاده از شبكه عصبى

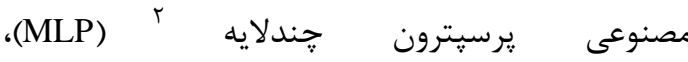

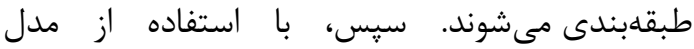
ركرسيون لجستيك، وزن بهينه هر يك ازبك، از عوامل تعيينشده و با استفاده از ضرايب بلهدست آمده از مدل بهرئ

${ }^{2}$ Multi Layer Perceptron
سيستم اطلاعات مكانى (GIS)' و سنجشازدور را در به تصوير كشيدن رشد هرز گونهى شهرى و تغييرات كاربرى زمين بررسى كردند. نتايج بلوضوح نشان دادند

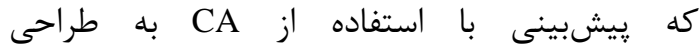
يك سيستم پايدار شهرى كمك مينمايد [ه]. منشى و

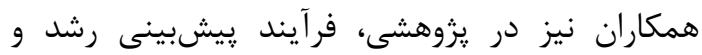
توسعهى شهر احمدآباد هندوستان را با استفاده از

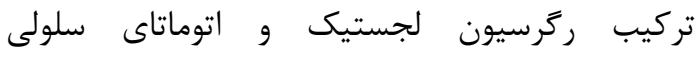
اجرا نمودند. بررسىهاى دقيقتر نشان مىدهند كه محققين مذكور با استفاده از ابزارهاى موجود سعى در

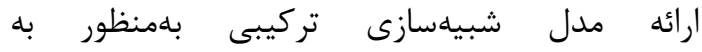
تصوير كشيدن اثرات آيندهى توسعهى شهرى در كنار

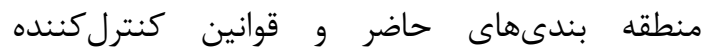

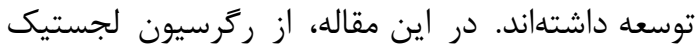

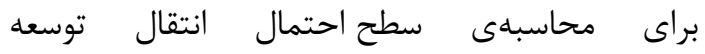
استفادهشده و همزمان بهمنظور شبيهسازى ميزان تغييرات و رشد شهرى مدل تعامل مكانى بر يايه

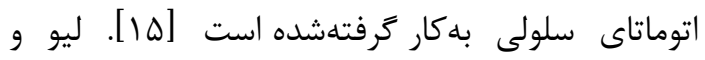

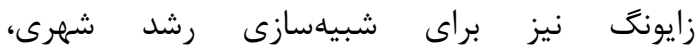
الكوهاى توسعهى شهرى و خطرات زيستمحيطى رات تحليل نمودند. در اين مطالعه از يكى مدل تركيبى شامل رگرسيون لجستيك خودكار، زنجيرهى ماركوف و لمونين

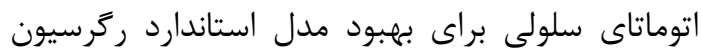
لجستيك استفاده شد [س]. ازجمله عوامل تاثيرگذار در رشد شهرى سياستها و برنامهريزىهاى مديران شهرى مىباشد. عدم توجه به فاكتور مذكور و تاثير آن در شبيهسازى رشد شهرى مهرى سبب غيرواقعبينانه شدن نتايج خواهد شد. از طرفى ديخر به دليل زيجيدگى موجود در سيستمهاى شهرى، فرآيند رشد آنها به فاكتورهاى زيادى وابسته است. لذا وسعت و تنوع فاكتورهاى در نظر كرفتهشده بهعنوان ورودى مدل، كمك شايانى بهواقع بينانه بودن

${ }^{1}$ Geospatial Information System 
مطابق با قوانين انتقال در لحظه 1+1، بر اساس وضعيت

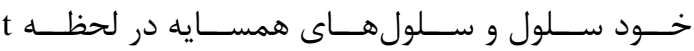

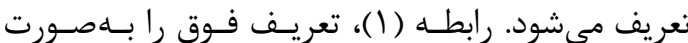

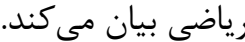

$$
S_{x i j}^{t+1}=\mathrm{f}\left(S_{x i j}^{t}, S_{X i j}^{t}\right) \quad \text { (1) }
$$

در رابط فـوق،

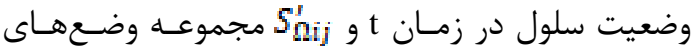
ممكن در زمان t g ت ابع بيان كننده مجموعـه قـوانين

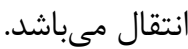

\section{- تحليل حساسيت:}

بلهعلت تأثيرى كه مقياس و نوع همسـايكى بـر رفتـار و خروجى مدل CA دارد، برخى از محققين ازجمله منارد

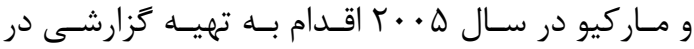
ارتباط با حساسيت مدل CA با توجه به مقياس مكـانى

و وضعيت سلول نمودند [IV]

$$
\text { - - - اتوماتاى سلولى فازى: }
$$

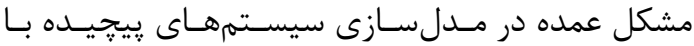

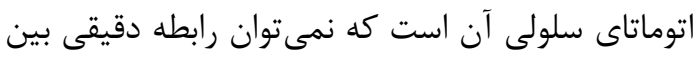

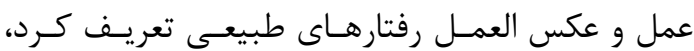

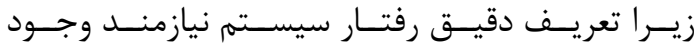

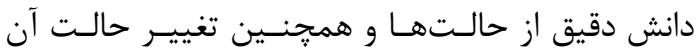

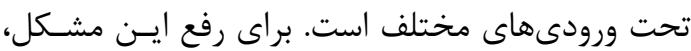
از منطق فازى بهمنظور تعريف كميتهـاى غيردقيـق و مبهم موثر در تصميمى ميرى درباره قوانين انتقال و تغيير

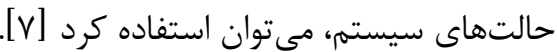

مذكور، نقشه هميوشانى تهيه مىشود. در مرحله بعد با

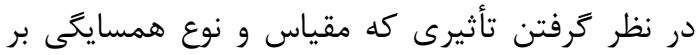
رفتار خروجى مدل CA دارد، تحليل حساسيت ييادهازى شده و بر اساس نتايج آن، الكَريتم

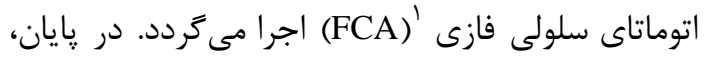

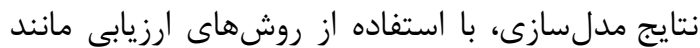
شاخص كايا و ماتريس خطا موردبررسى قراركرفته و نتايج حاصل بهمنظور يِيشبينى محدودههاى مستعد و و ارائه راهكارهاى عملياتى بهينه بررسى مىشوند.

\section{r- فلوجارت و روش تحقيق}

با توجه به فلوحارت تحقيق در شكل (1) مراحلى شامل

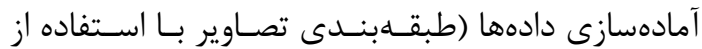

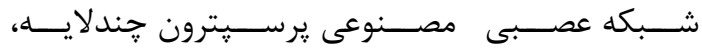

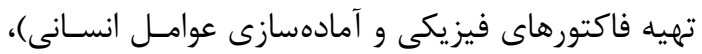

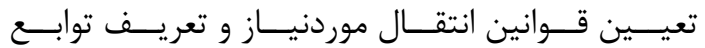
عضويت مجموعههاى فازى، تعيين وزن بهينه عوامل بـا

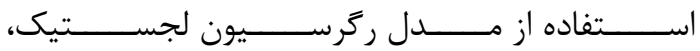
ايجاد نقشه هميوشانى، اجراى آناليز حساسيت و بررسى الري

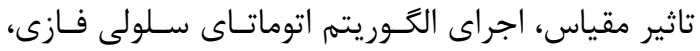

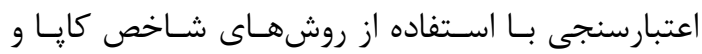
ماتريس خطا، طى شـده اسـت كـه نحـوه وٍيـادهــازى

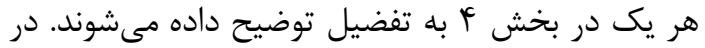

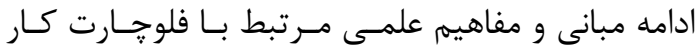
شامل اتوماتاى سلولى، شبكه عصبى مصنوعى خندلايلها

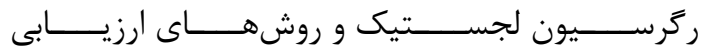
تشريح مى r-1- اتوماتاى سلولى

بر اساس تعريف ولفــام، اتوماتـاى سـلولى يــ فضـاى

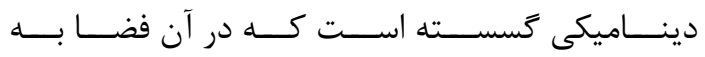

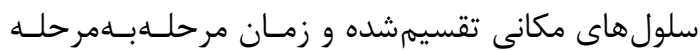

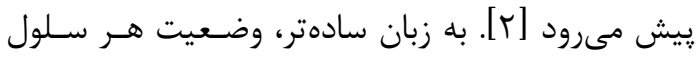

${ }^{1}$ Fuzzy Cellular Automata 


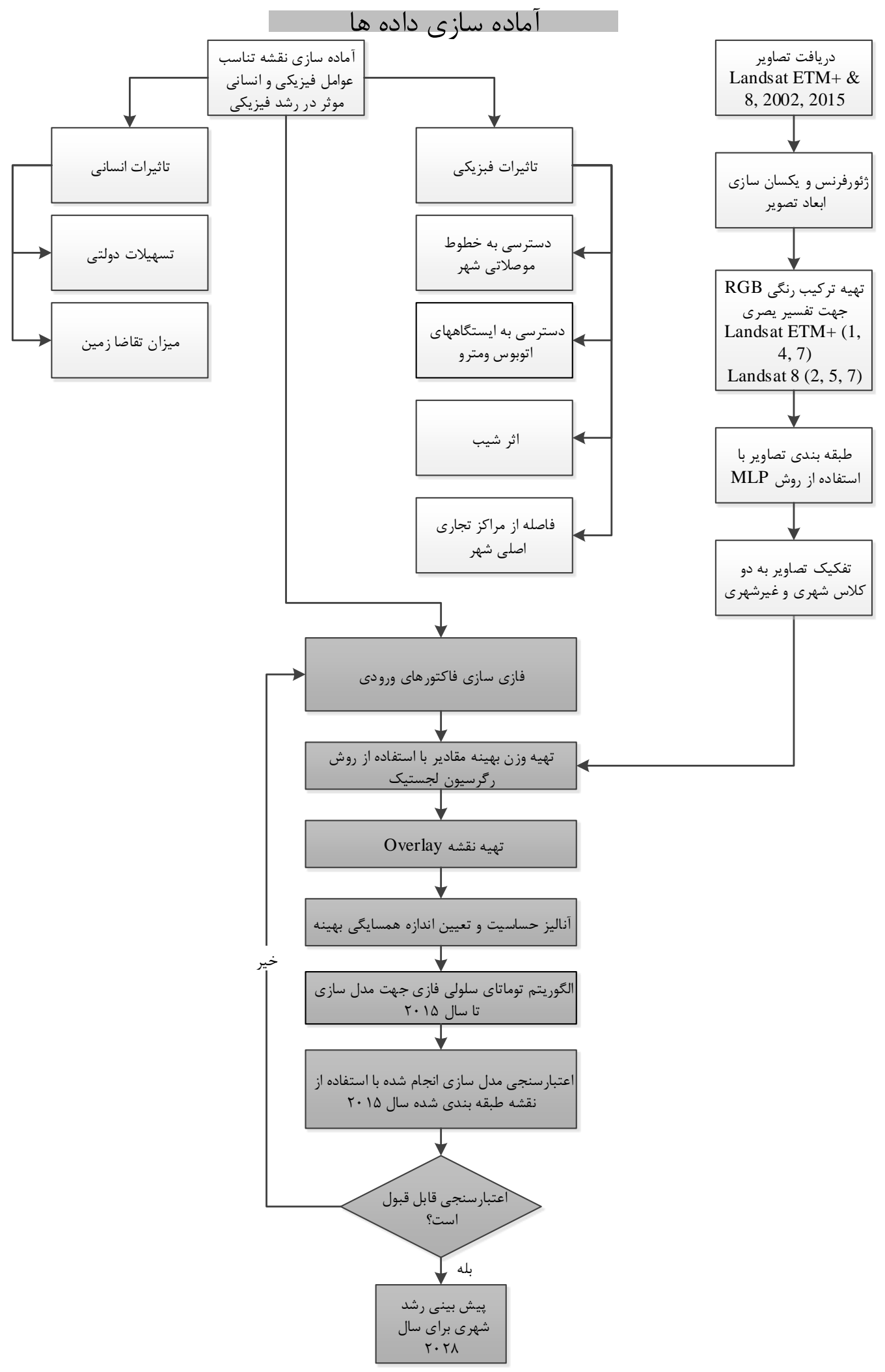

شكل ا: فلوحارت مراحل تحقيق 


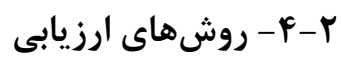

تعيين ميزان انطباق مدل با واقعيت، مرحلـه مهمسى در

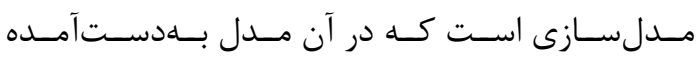

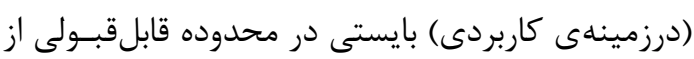

$$
\text { دقت رضايتبخش قرار كيرد. }
$$

• ماتريس خطا: يكسى از ابزارهـاى متـداول جهـت

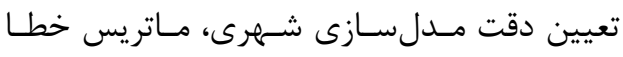

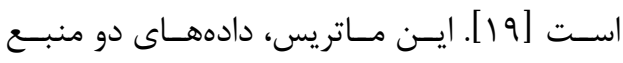

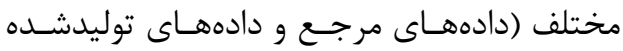
توسط مدل) را طبقهبندى مى كند و روابط ميـان

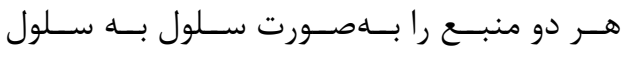
مقايسه مىنمايد.

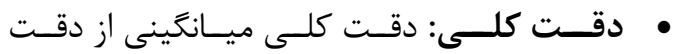

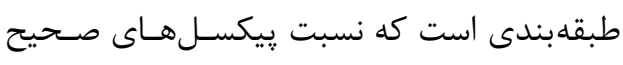
طبقهبندى شده به جمع كل بيكسل هاى معلوم رأ

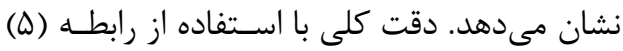
برآورد مىشود.

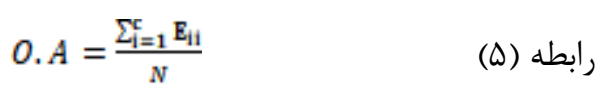

در رابطه فوق، c تعداد رهها، N تعداد كل ييكسل هــاى معلوم،

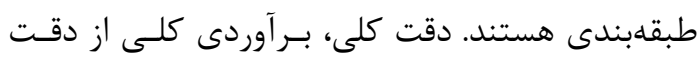

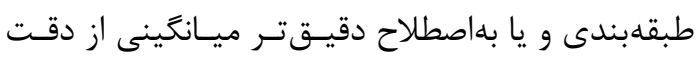
طبقهبندى هستند.

شاخص كايا: ضـريب كايـا دقـت طبقـهنـــــ را

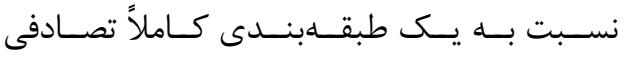

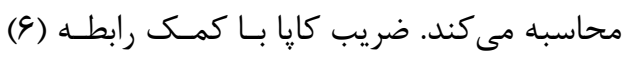

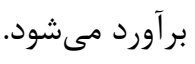

رابطه (ع)

$=\frac{\mathbf{n} \sum_{i=1}^{k} \mathbf{n}_{i i}-\sum_{i=1}^{k} \mathbf{n}_{i+} \mathbf{n}_{+i}}{\mathbf{n}^{2}-\sum_{i=1}^{k} \mathbf{n}_{i+1} \mathbf{n}_{+i}}$ ni $=1 \mathrm{knii}-\widehat{\mathbf{K}}$

$\mathrm{i}=1 \mathrm{kni}+\mathrm{n}+\mathrm{in} 2-\mathrm{i}=1 \mathrm{kni}+\mathrm{n}+\mathrm{i}$
r-Y-Y شبكه عصبى ڤبرسيترون جندلايه

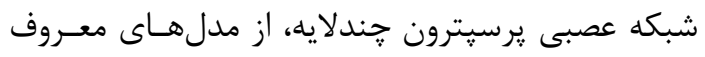

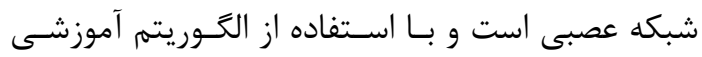

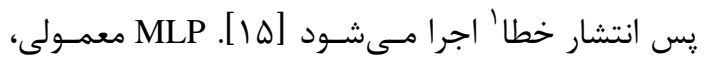

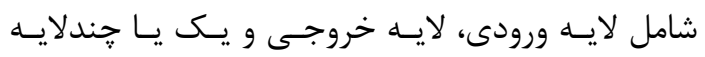

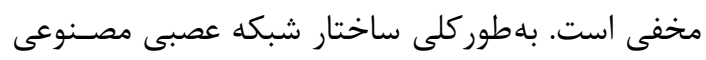

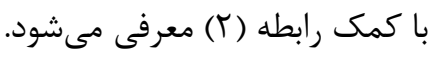

$$
\text { Net }
$$

در رابطه بالا، Oا $O_{i}$

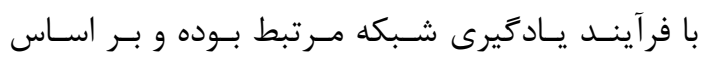
رابطه (广) محاسبه مىشود.

$$
\text { RMSE }=\sqrt{\frac{\sum_{K=1}^{K}\left(X_{K}-Y_{K}\right)^{2}}{K}} \quad \text { (ए) }
$$

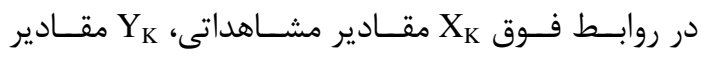
برآورد شده و K تعداد دادهها مى باشد. r-r- ر

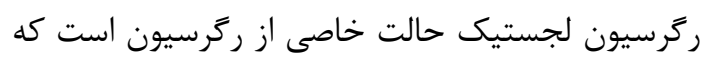

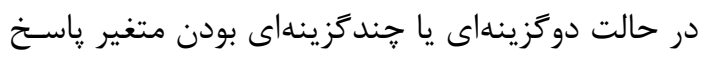

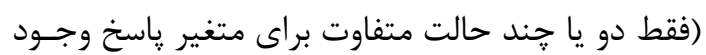

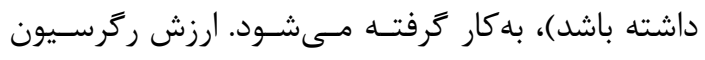

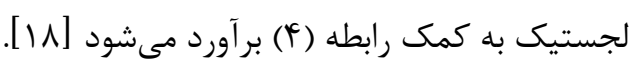
رابطه (f)

$\operatorname{Logistic}(\mathrm{p})=\ln \left(\frac{\mathrm{p}}{\mathrm{I}-\mathrm{p}}\right)=\alpha+\beta_{1} \mathrm{x}_{1, \tilde{\mathrm{i}}}+\ldots .+\beta_{\mathrm{k}} \mathrm{x}_{\mathrm{k}, \mathrm{i}}$ در اين مدل، p احتمال تعلق فرد به سـطح اول (متغيـر

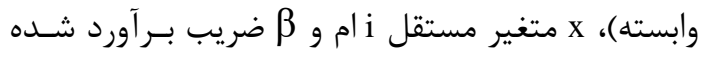

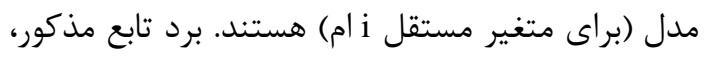

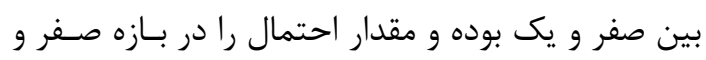
يك نشان مى دهد.

${ }^{1}$ Back Propagation 
لندست ^ (سال ه| • ץ) استفاده شد. سيس، با استفاده

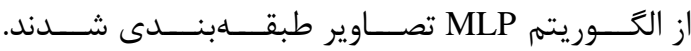

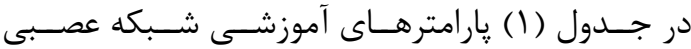
طراحىشده، آورده شده است.

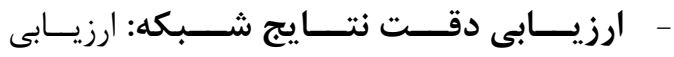

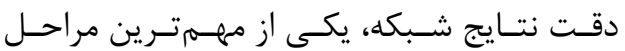

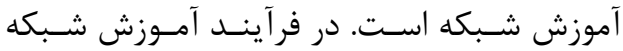

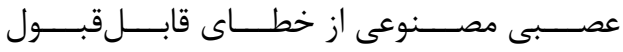

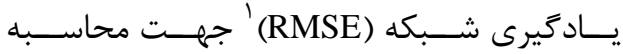

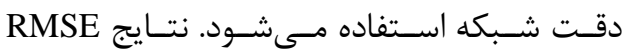

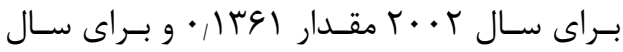

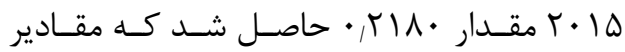
بلدست آمده نشانگر دقت بالاى شبكه هستند. طبقه بندى تصاوير: يسس از تعيـين RMSE، از شبكه بهينــه حاصـله بــراى طبقـــبنـدى تصـاوير

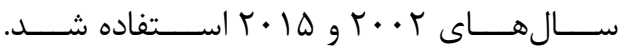
نقشه يوشش اراضى بلهدست آمـده بــراى هرسـال،

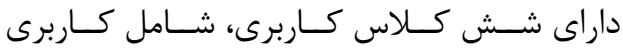
انسان ساخت، فضاى سبز و باغات، مراتع، اراضى

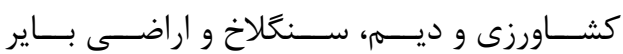

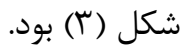

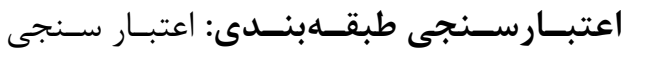
نقشههاى طبقلبندى شده با استفاده از دقت كلى

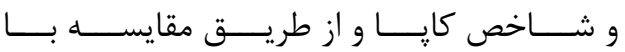

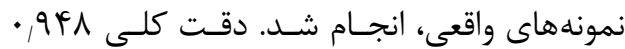

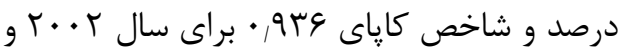

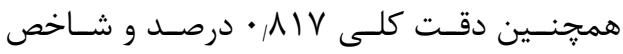

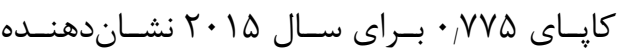

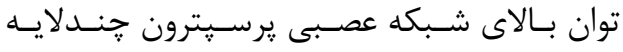
جهت طبقهبندى تصاوير مىباشد.

\footnotetext{
${ }^{1}$ Root Mean-Square Error
}

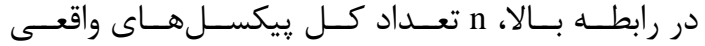

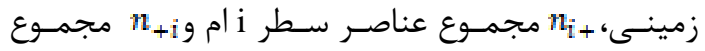
عناصر ستون i ام هستند. r - منطقه موردمطالعه

شهر مشهد با طول جغرافيايى هو درجه و ها دقيقه تـا • ع درجه و وس دقيقه و عرض جغرافيـايى ها درجـهـ و rF دقيقه تا MV درجه و 1 دقيقه در شمال شرق ايسران

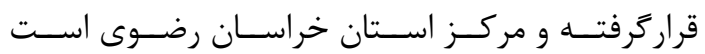
(شكل (r)). اين شهر يس از تهران، بـزرتَتـرين شـهر

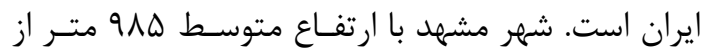

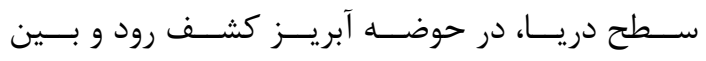

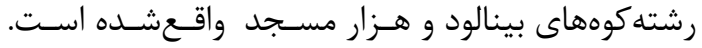
عواملى از قبيل رشد صـنعت و خـدمات توريسـتى و در

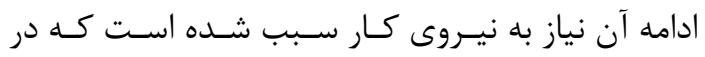
سده اخير، شهر مشهد رشد جمعيت بالايى داشته باشد. بنابراين محاسبه روند رشد شهر مشهد كمك شايانى به برنامهريزان و مديران شهرى ارائه خواهد نمود.

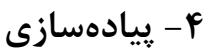

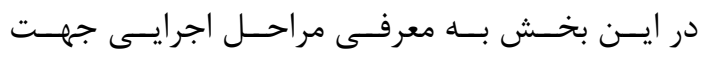

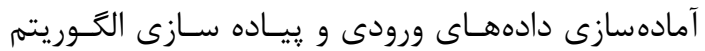
مورد نظر يرداخته مىشود. F -1- آمادهسازى دادههاى ورودى در ادامــه جهـت توليــد فاكتورهــاى موردنيــاز نحــوه آمادهسازى دادهها بررسى مىشود. بهاينترتيـب كـه در

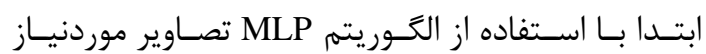

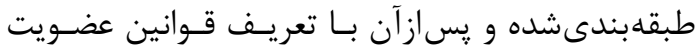

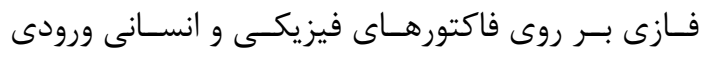

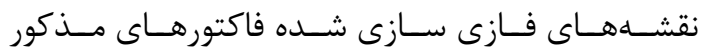

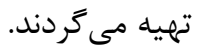

الف) تهيه نقشه كاربرى اراضى شهرى

در اين مقاله جهت تهيه نقشـههـاى يوشـش اراضـى از

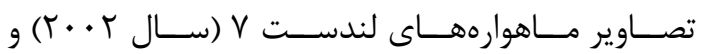




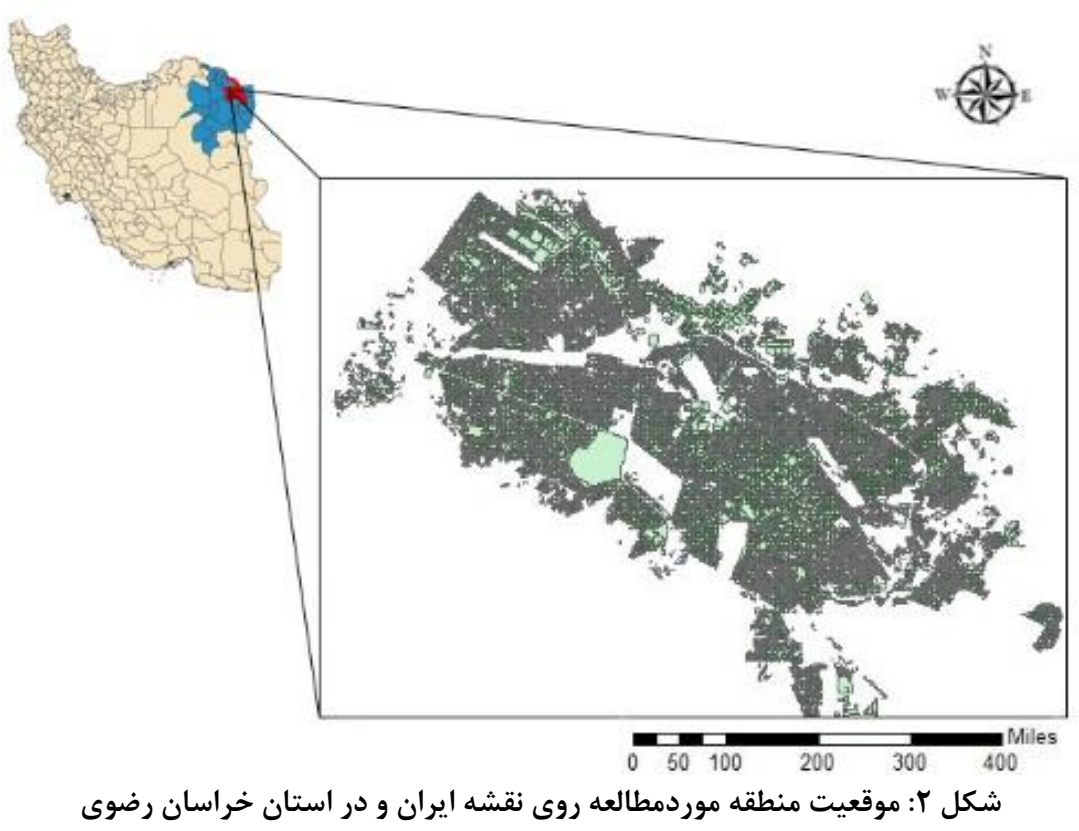

\begin{tabular}{|c|c|c|c|c|}
\hline تعراد & نرخ خطاى قابلقبول & تعداد نرونهاى لايه & تعداد نرونهاى لايه & تعداد نرونهاى لايه ورودى \\
\hline $1 \cdots$ & $\mathrm{RMSE}=0.01$ & $\begin{array}{c}\text { ع نرون (كلاسهاى كاربرى) } \\
\text { كاى }\end{array}$ & 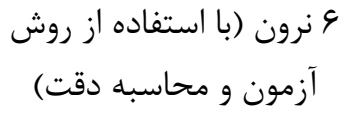 & 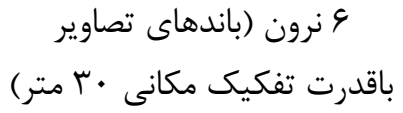 \\
\hline
\end{tabular}

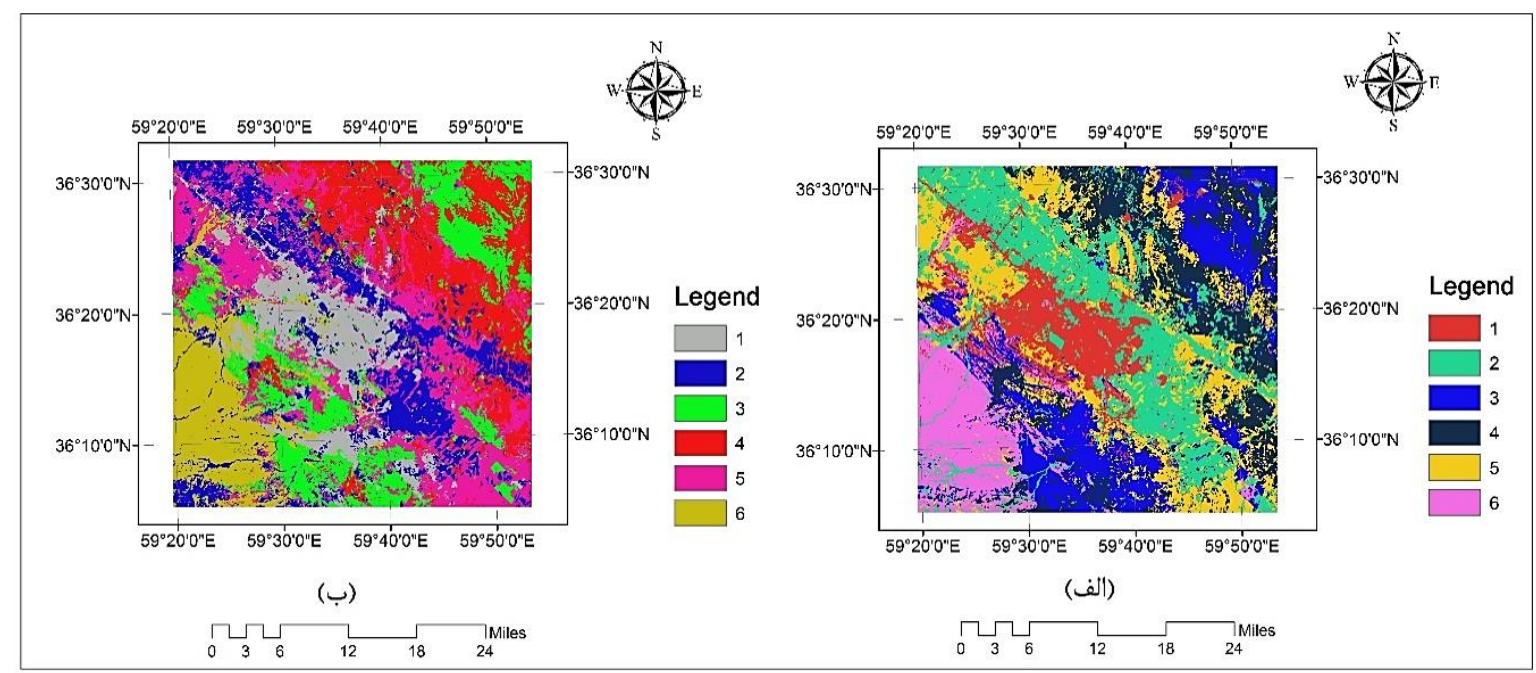

شكل r: نقشه كاربرى اراضى شهر مشهد. الف) نقشه كاربرى اراضى سال r.+r، ب) نقشه كاربرى اراضى سال ها.r'

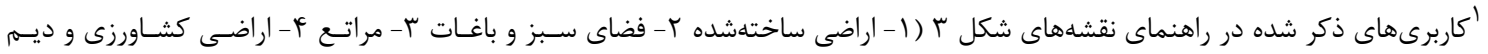

$$
\begin{aligned}
& \text { ه- اراضى باير \&- سنخلاخ) }
\end{aligned}
$$


خطى توابع عضويت فاكتور مذكور تعريف گرديده

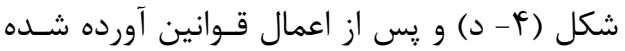

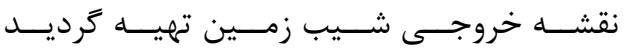
(شكل(4- ()). • مراكز تجارى اصلى (CBD)'؛ مناطق نزديكتـر به مراكز تجارى ارزش بيشترى نسـبت بـهـ سـاير

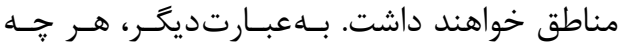

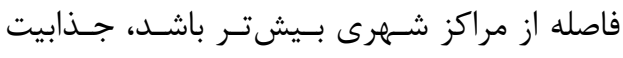

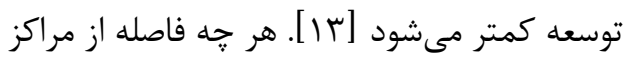
تجارى اصلى مذكور كسم، متوســ و زيـاد باشـد، خروجسى متغيــر رشـد شـهرى بــه ترتيـب زيــاد،

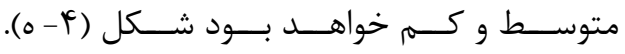

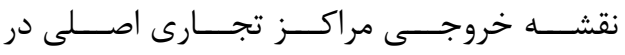
شكل (9-0) قابلمشاهده است.

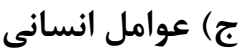

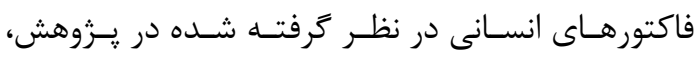

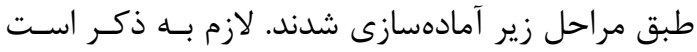
كه با توجه به حداقل و حداكثر مقدار فاصـله از عوامـل فيل فيزيكى در نظر كرفتهشده در اين تحقيق، ابتـدا فاصـله

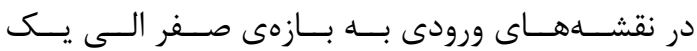

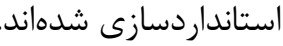

• تسهيلات دولتسى: تقاضـا و تسـهيلات اعطـايى

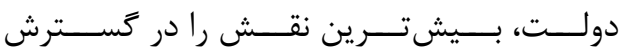

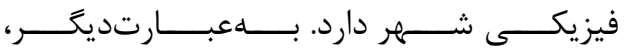

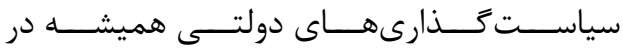

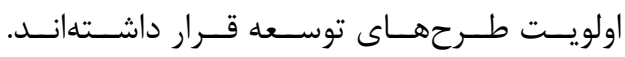
لذا در اين يزوهش، ميزان تعلق تسهيلات دولتسى

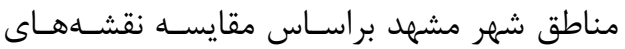

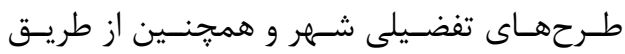
مصاحبه با كارشناسان مربوطه بهدست آمده است.

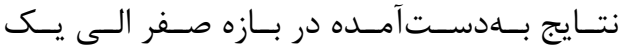

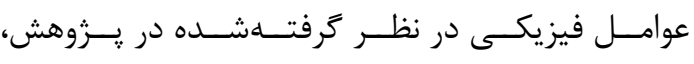
طبق مراحل زير آمادهسازى شدند. لازم به ذكر است كه

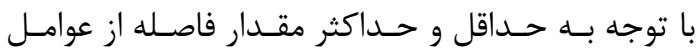
فيزيكى در نظر كرفتهشده در اين تحقيق، ابتـدا فاصـله

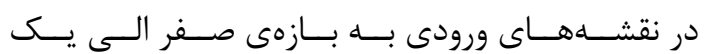
استانداردسازى شده و در ادامه با توجه به تعاريف زبانى

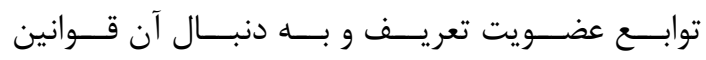

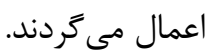

• دسترســى بــه خطــوط مواصــلاتى شــهر:

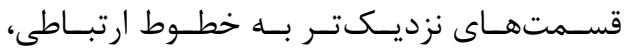

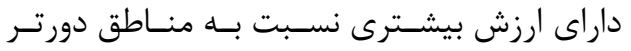

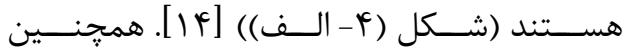
قوانين انتقال نيز به اين صورت تعريف شدند كـهـ اكر دسترسى بـه خطـوط مواصـلاتى شهر كمه، متوسط و زياد باشد، خروجى متغير رشد شهرى اهرى بلهترتيب زياد، متوسط و كمم خواهـــ بـود (شـكل (9- (الف)).

\section{داسترسى به ايستخاههاى اتوبـوس و متــرو:}

از ديكر عوامل تأثير كذار بر رشد شهرى، مىتــان به ناوكان حملونقل عمومى شهرى اشـاره كـرد.

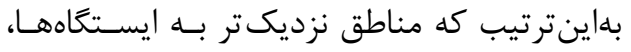

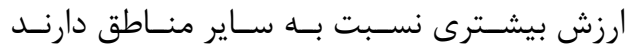

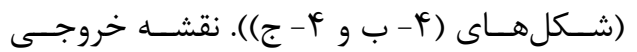

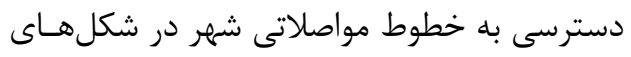
(צ- ب و 9- ج) قابل مشاهده است. شيب: شيب زمين به علت ميزان تأثيرى كـهـ بـر

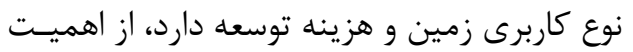

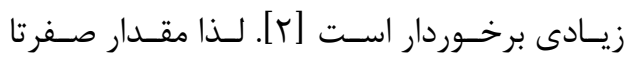
دو درصــد بــراى شــيب زمــين در شهرســازى

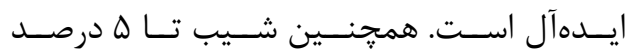
مناسب بوده و بيش از نه درصـد نامناسـب اسـت.

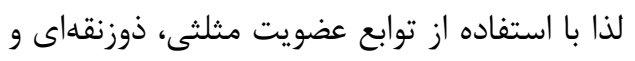


متوسط و كم خواهد بود. نقشـه خروجى ميـزان

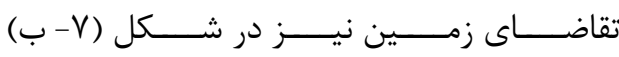
قابل مشاهده است.

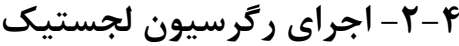

مرسومترين متد جهت كاليبراسيون مدلهاى CA

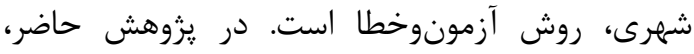

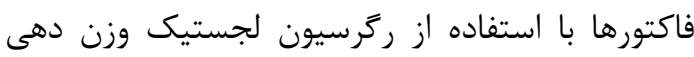

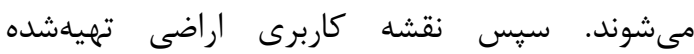

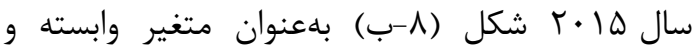

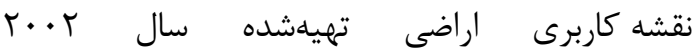
شكل (^- الف) و فاكتورهاى انتخابشده بهعنوان متغيرهاى مستقل به ركرسيون معرفى شدند. با اجراى الئ

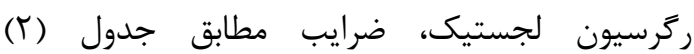

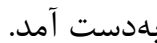

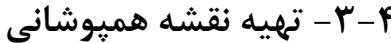

هدف از تهيه نقشه هميوشـانى، ارزشكـــارى فاكتورهـا

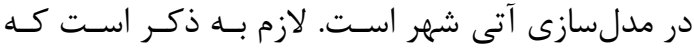

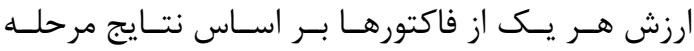

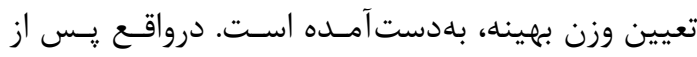

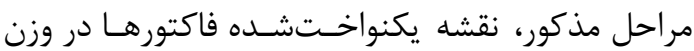

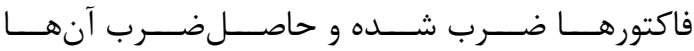

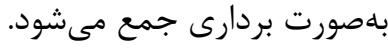

استانداردسازى شده و بر اسـاس تعـاريف زبـانى و

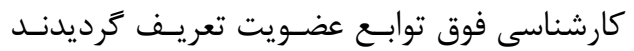

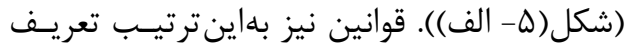

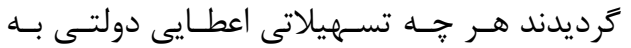

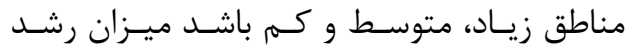
شهرى در آن مناطق به ترتيب زياد، متوسط و كم خواهد بود. شكل (V- الف) نيز نشاندهنده نقشئهـ خروجى فاكتور تسهيلات شهرى است.

• ميزان تقاضاى زمين: جهت تهيه لايه تقاضـا، از

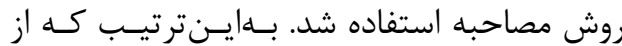
هر محله، يك آزانس معاملات املاك انتخاب شـد التهد

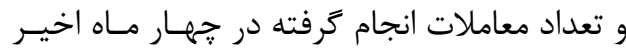
بهنوان ورودى اين لايسهـ (جهـت ارزشكَـارى)،

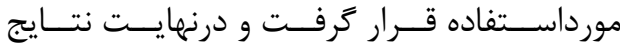

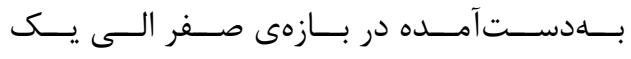

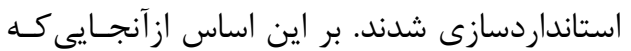

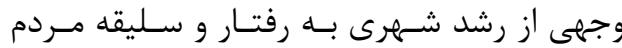

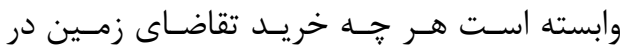

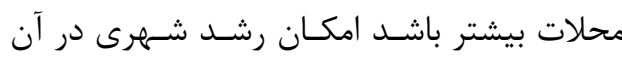
مناطق بيشتر خواهد بود. بر اساس تعريف مـذكور توابع عضويت شكل (ه- ب) شـكل گرفتــه اسـت.

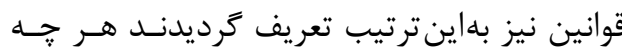

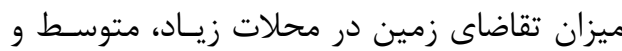
كم باشد ميزان رشد شهرى نيز بـه ترتيسب زيـاد، 

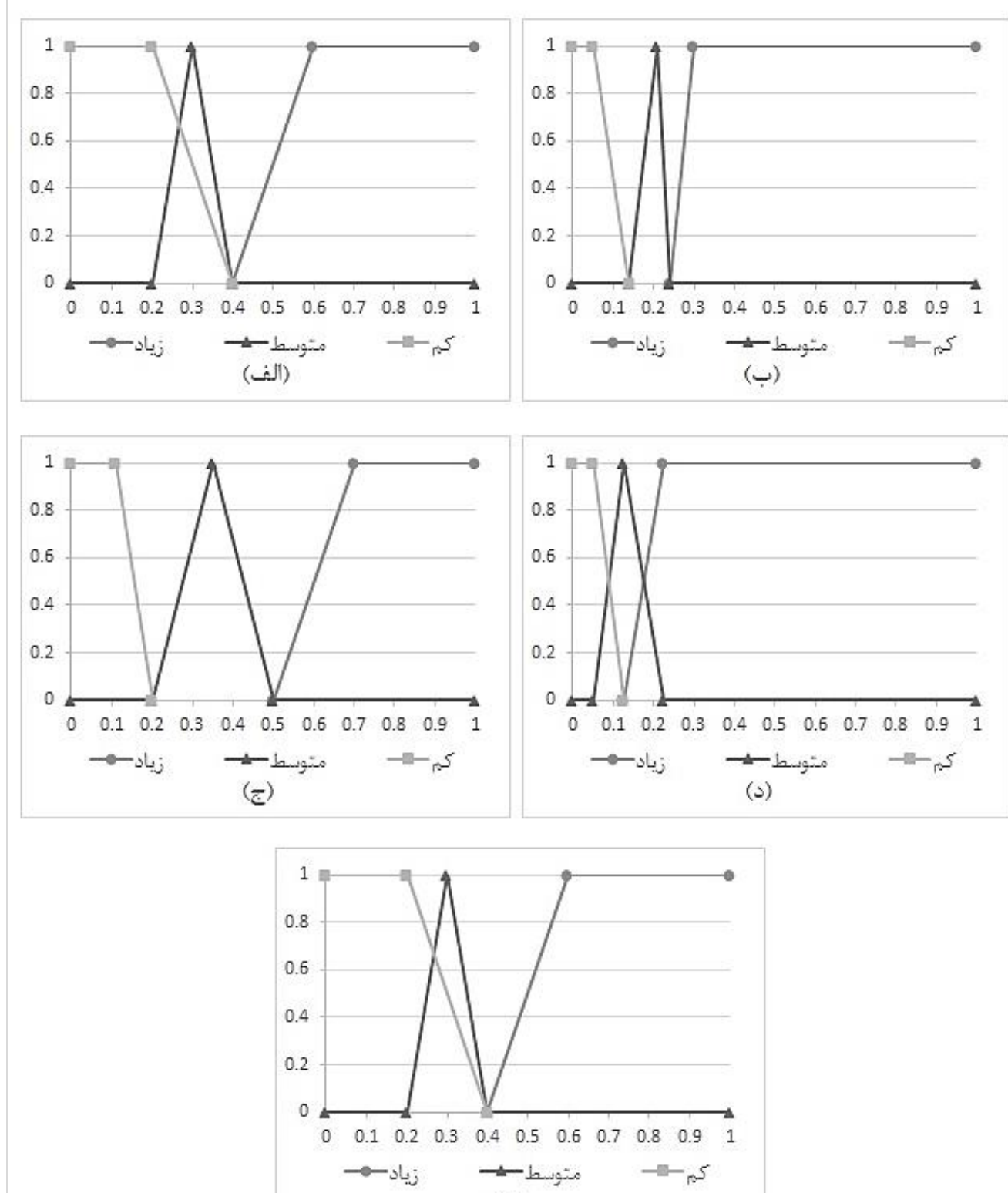

(o)

شكل f: توابع عضويت تعريفشده (دسترسى به خطوط مواصلاتى شهر (الف)، دسترسى به ايستخاههاى اتوبوس (ب)،

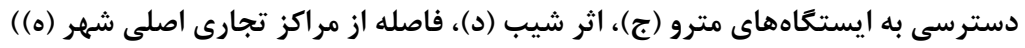



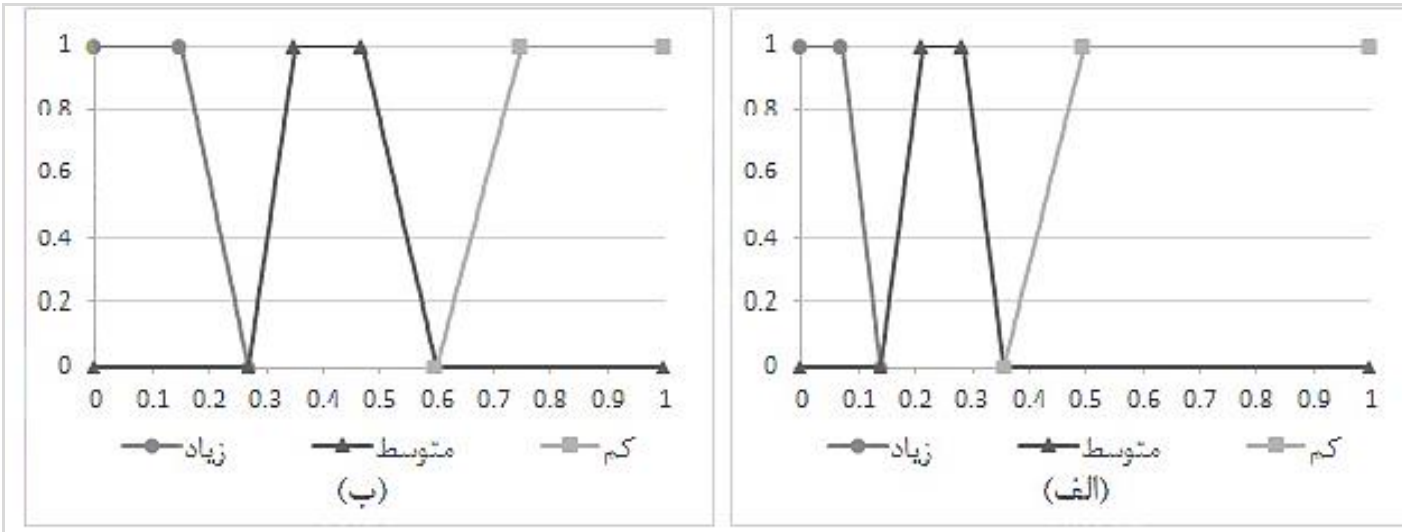

شكل ه: توابع عضويت تعريفشده (تسهيلات دولتى (الف) و ميزان تقاضاى زمين (ب))

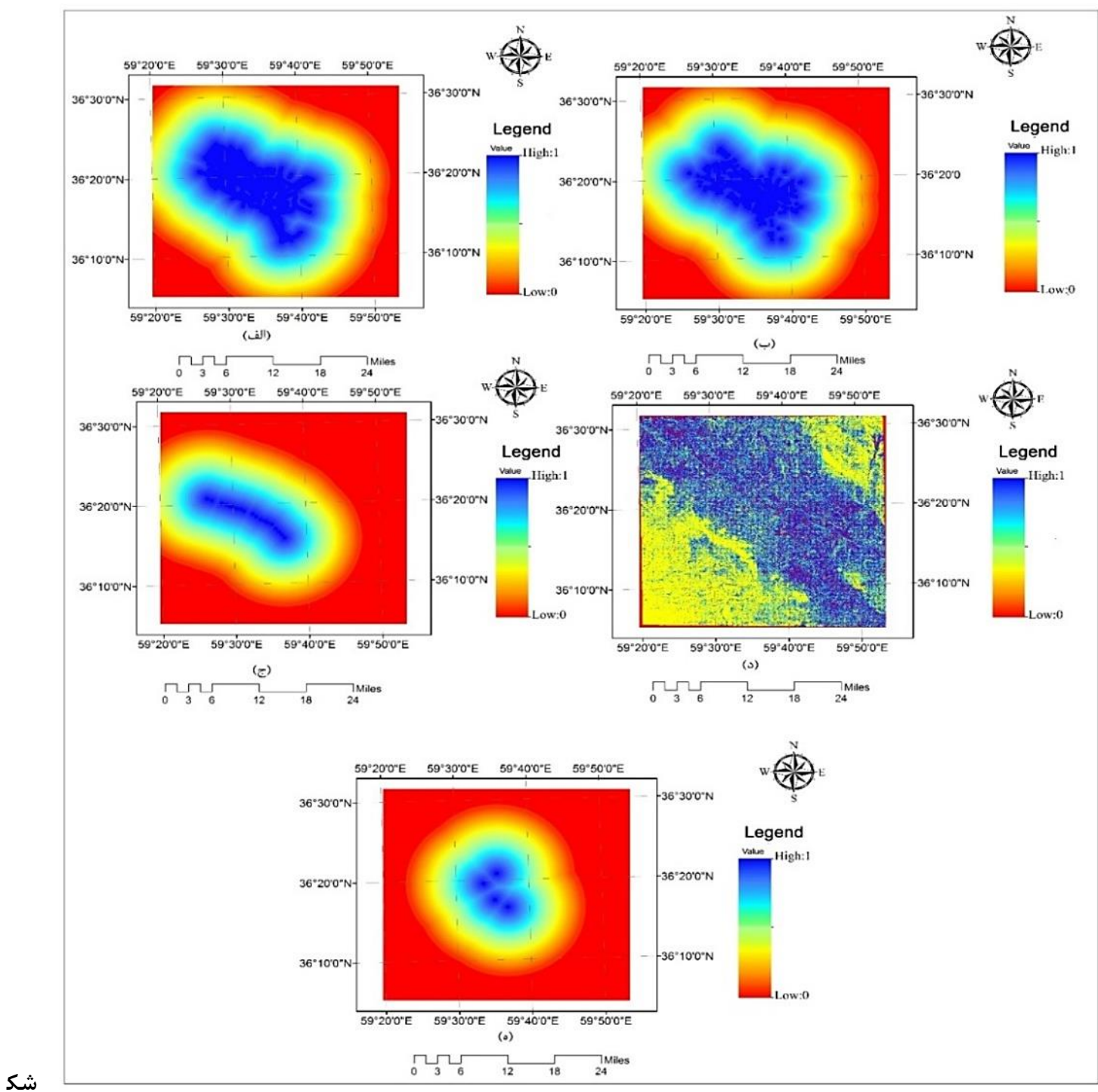

شكل 9: نقشه هاى فازى سازى شده (دسترسى به خطوط مواصلاتى شهر (الف)، دسترسى به ايستعاههاى اتوبوس (ب)،

دسترسى به ايستخاههاى مترو (ج)، اثر شيب (د)، فاصله از مراكز تجارى موسى اصلى شهرى (ه) () ) 
مدلحسازى و يِيشبينى رشد افقى شهر مشهد با استفاده ...

فرهاد رستمى كَله، مرجان قائمى، روزبه شاد، ياسمن لهر ابى ليى لئي

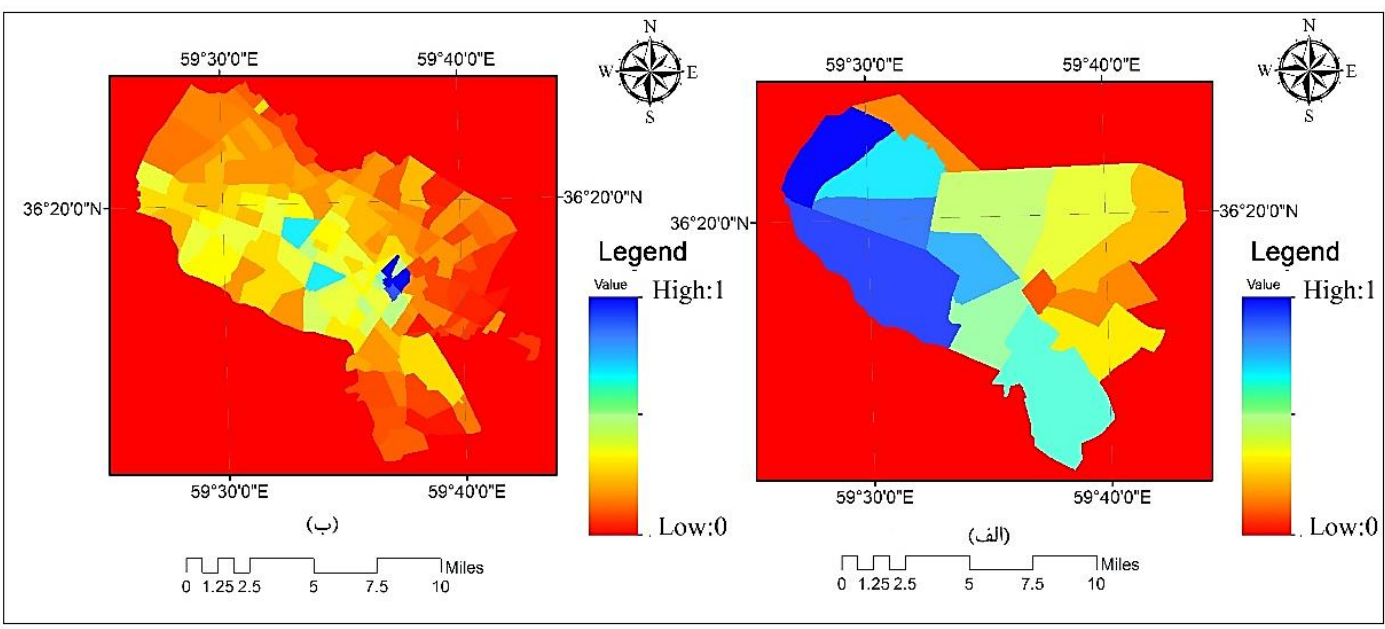

شكل V: نقشههاى فازىسازى شده (تسهيلات دولتى (الف) و ميزان تقاضاى زمين (ب))

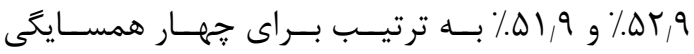

P-F

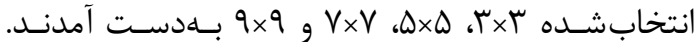

به علت تأثيرى كه مقياس و نوع همسايكى بـر رفتـار و بنابراين مطابق نتايج بdدسـتآمــده، مشــص شـــ كـهـ خروجى مدل CA دارد، اين مـدل بــا اسـتفاده از جهــار

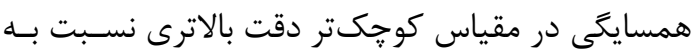
همسايخى در مقياس بالاتر دارد.

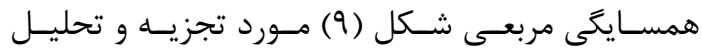

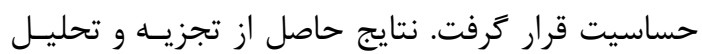

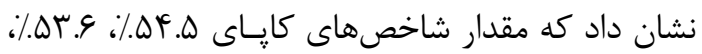

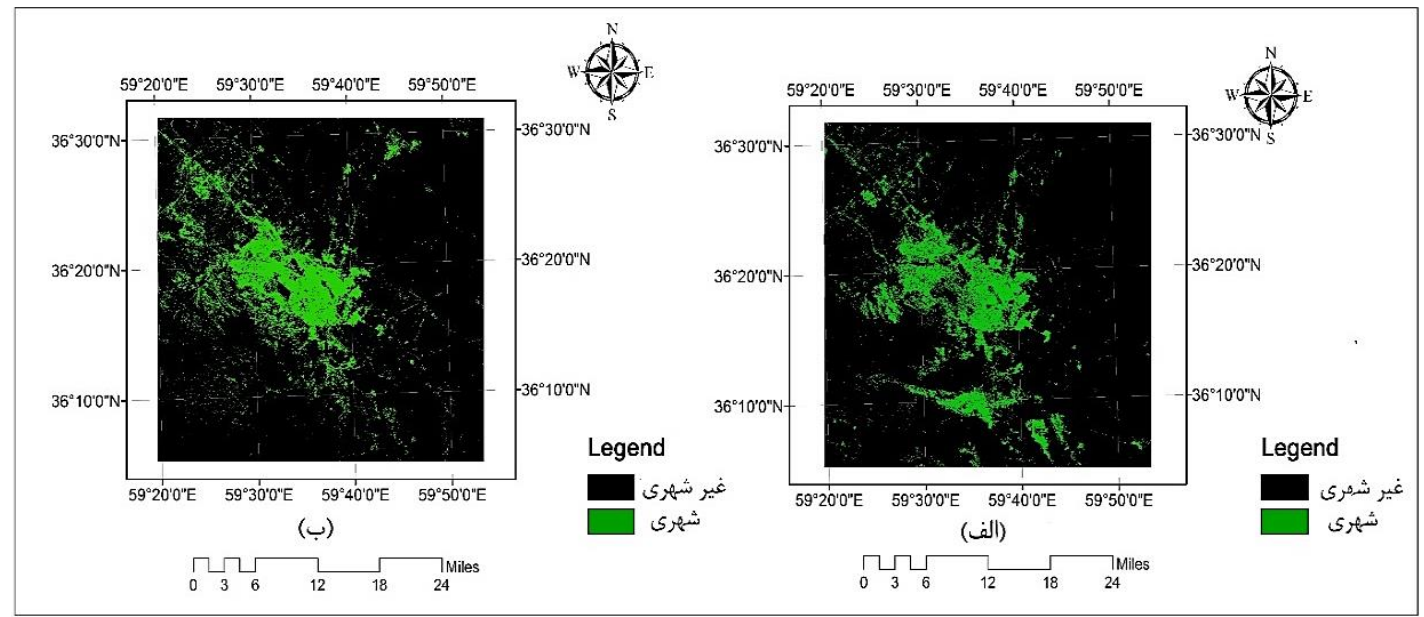

شكل ^: نقشه كاربرى اراضى انسان ساخت

جدول ז: ضرايب بهدست آمده از ركرسيون لجستيك

\begin{tabular}{|c|c|c|c|}
\hline 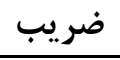 & متغير مستقل & 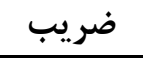 & متغير مستقل \\
\hline$-v p q q$ & دسترسى به ايستخاههاى مترو & $-\cdot, T I V G$ & اثر شيب \\
\hline$r, q 9 \cdot r$ & دسترسى به خطوط مواصلاتى شهر & $r, T G \cdot \Delta$ & اراضى ساختهشده سال r •. r \\
\hline • rprq & فاصله از مراكز تجارى اصلى شهر & • & تسهيلات دولتى \\
\hline - IgAF & ميزان تقاضاى زمين & $-\cdot \cdot \cdot 4 q \mu$ & دسترسى به ايستخاههاى اتوبوس \\
\hline
\end{tabular}




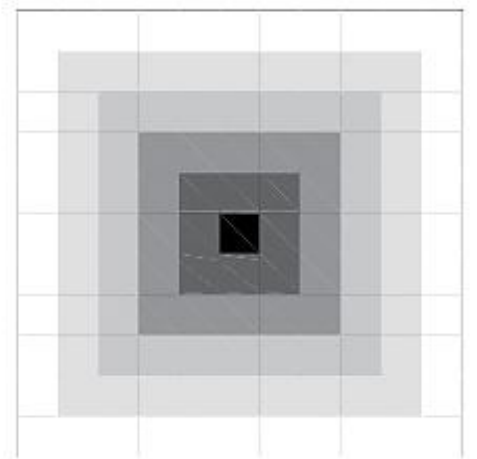

(ง)

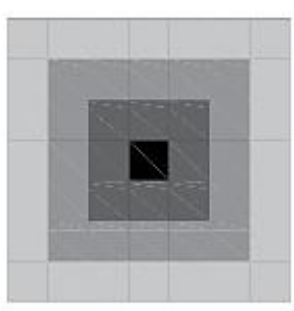

(飞)
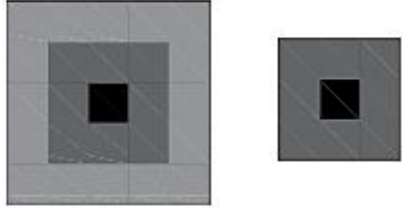

(ب)

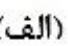

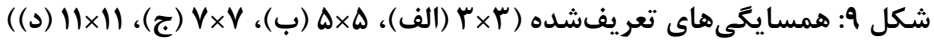

باشد، خروجـى متغيـر رشــ شهرى بـهـ ترتيـب زيـاد،

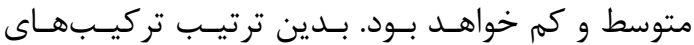

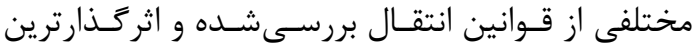

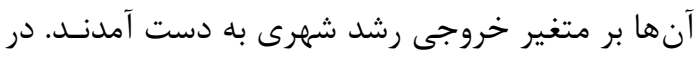
اين حالت اتوماتاى سلولى فازى امكان تعلق هر بريكسل

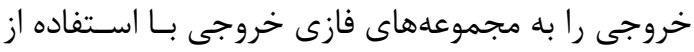
ارزيابى توابع عضويت بهينه مشخص مىنمايد. با اعمـال قوانين انتقال فازى و تهيه نقشـهـ هميوشـانى، الخَــوريته

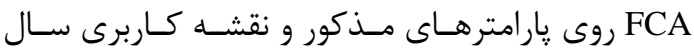

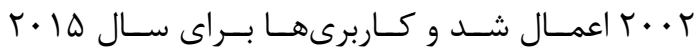

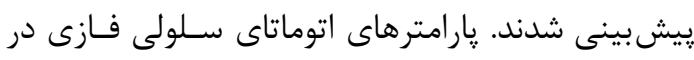

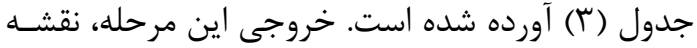

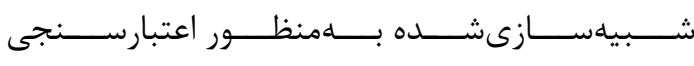
شكل (•) - (1) مىباشد.

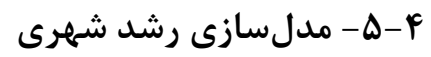

همانطور كه ذكر شد، براى بيادهسازى اتوماتاى سلولى

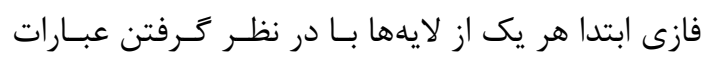
بيانى كم، متوسط و زيـاد فـازى سـازى شـده و وقـوانين

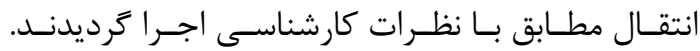
لايههاى ورودى بر مبناى متغيرهاى مسافت و تـراكم و

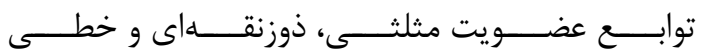
فازى سازى شدند. علاوه بر اين لايه خروجى رشد شـهر

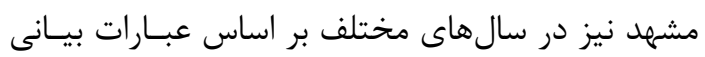

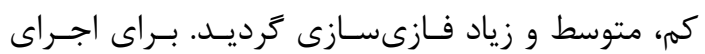

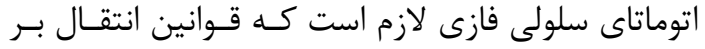

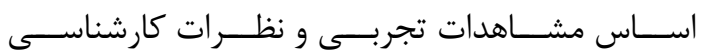
طراحى كردند. بـهعنـوانمثـال در قـوانين انتقـال، اخـر

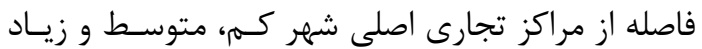

جدول ؟ّ: يارامترهاى اتوماتاى سلولى

\begin{tabular}{|c|c|c|c|c|}
\hline قوانين انتقال & زمان & همسايخى & وضعيت سلول & فضاى سلولى \\
\hline 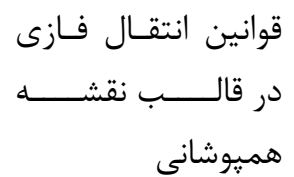 & $r \cdot r-r \cdot 10$ & حساسيت & شهرى-غيرشهرى & 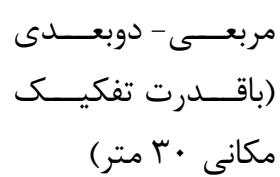 \\
\hline
\end{tabular}


مدلحسازى و ييشبينى رشد افقى شهر مشهد با استفاده ...

فرهاد رستمى كَله، مرجان قائمى، روزبه شاد، ياسمن لهرابى

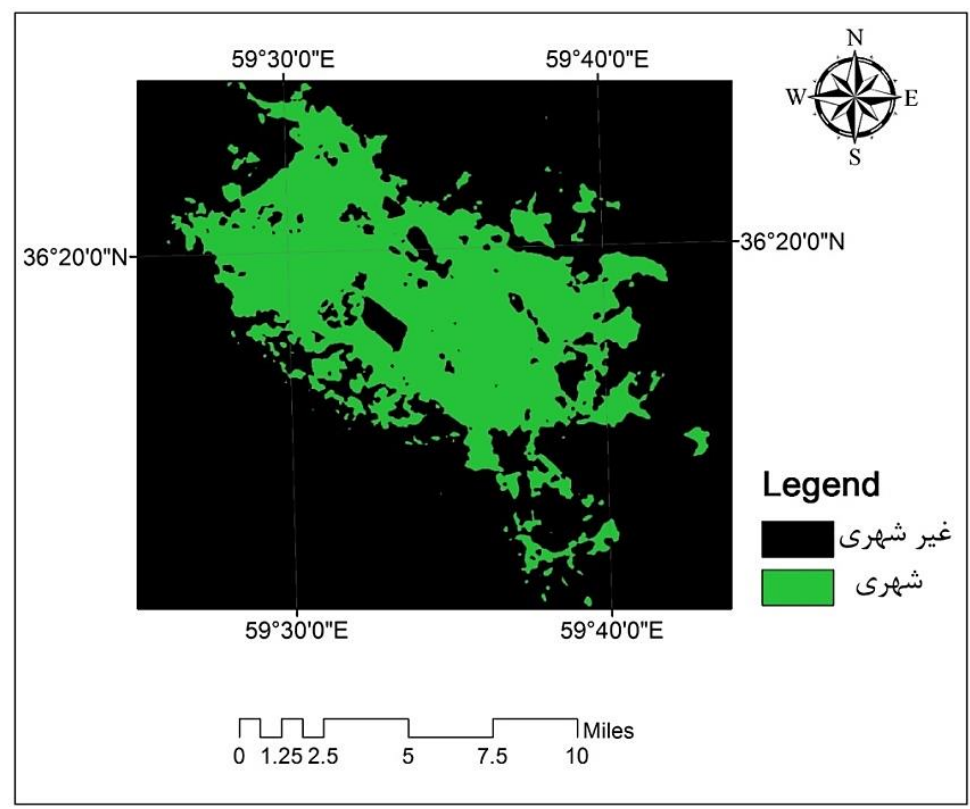

شكل •1: نقشه حاصل از اعمال مرحله مدلسازى

براى بررسـى دقيـقتـر صـحت عملكـرد روش تلفيقى F-9-9 اعتبارسنجى مدل

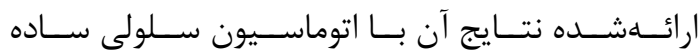
منظور از اعتبار سنجى آن است كه مدل در محدودهاى

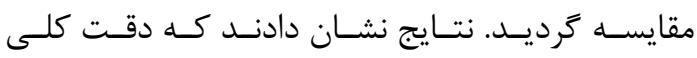
رضايتبخش از دقت قرارگرفته باشد. در اين مطالعـه از اتوماسيون ساده سلولى معادل با NV, درصد و و شاخص

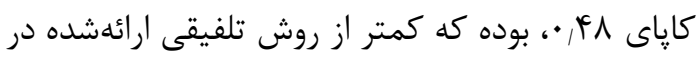

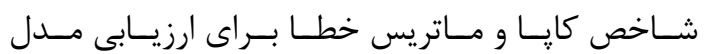

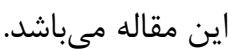

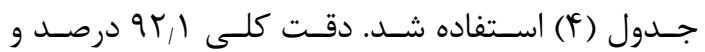
شاخص كاياى Ff • •، دستاورد تحقيـق حاضـر هسـتند.

جدول \&: نتايج ارزيابى طبقهبندى سال ها+ץ

\begin{tabular}{|c|c|c|c|c|}
\hline خطاى كاربر & كل & كلاس شهرى & كلاس غيرشهرى & \\
\hline $.1 .9 \mathrm{TTV}$ & $r \Delta \Delta \mid \Delta q r$ & IEIFFT & $r r q \cdot|\Delta|$ & كلاس غيرشهرى \\
\hline \multirow[t]{3}{*}{.$/ 49.94$} & r.gYAV & $|\Delta T E|$. & DrAVV & كلاس شهرى \\
\hline & $r \vee \Delta \Lambda \cdot \Lambda \cdot$ & $T I F \cdot \Delta T$ & TFFF. TA & كل \\
\hline & & $\cdot|\Delta| F \cdot G$ & $\cdot / \cdot r r \cdot r$ & خطاى توليدكننده \\
\hline \multicolumn{2}{|c|}{ | | | | ==دقت كلى } & \multicolumn{3}{|c|}{ } \\
\hline
\end{tabular}

بخش زيشبينى اتوماتاى سـلولى اسـتفاده شـــ و رشـــ

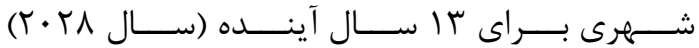
ييشبينى ميىشود. نتايج شكل (1) (1)، نشاندهنده رشـد شهرى است كه مى تواند به تصميمى گيرند شهرى در درى جشمهانداز ييش رو كمك شايانى كند.

- V- P ״س از كاليبراسيون مولفهاى تشكيل دهنده مدل و نيز

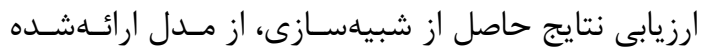

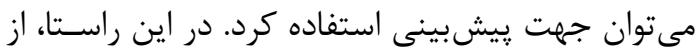




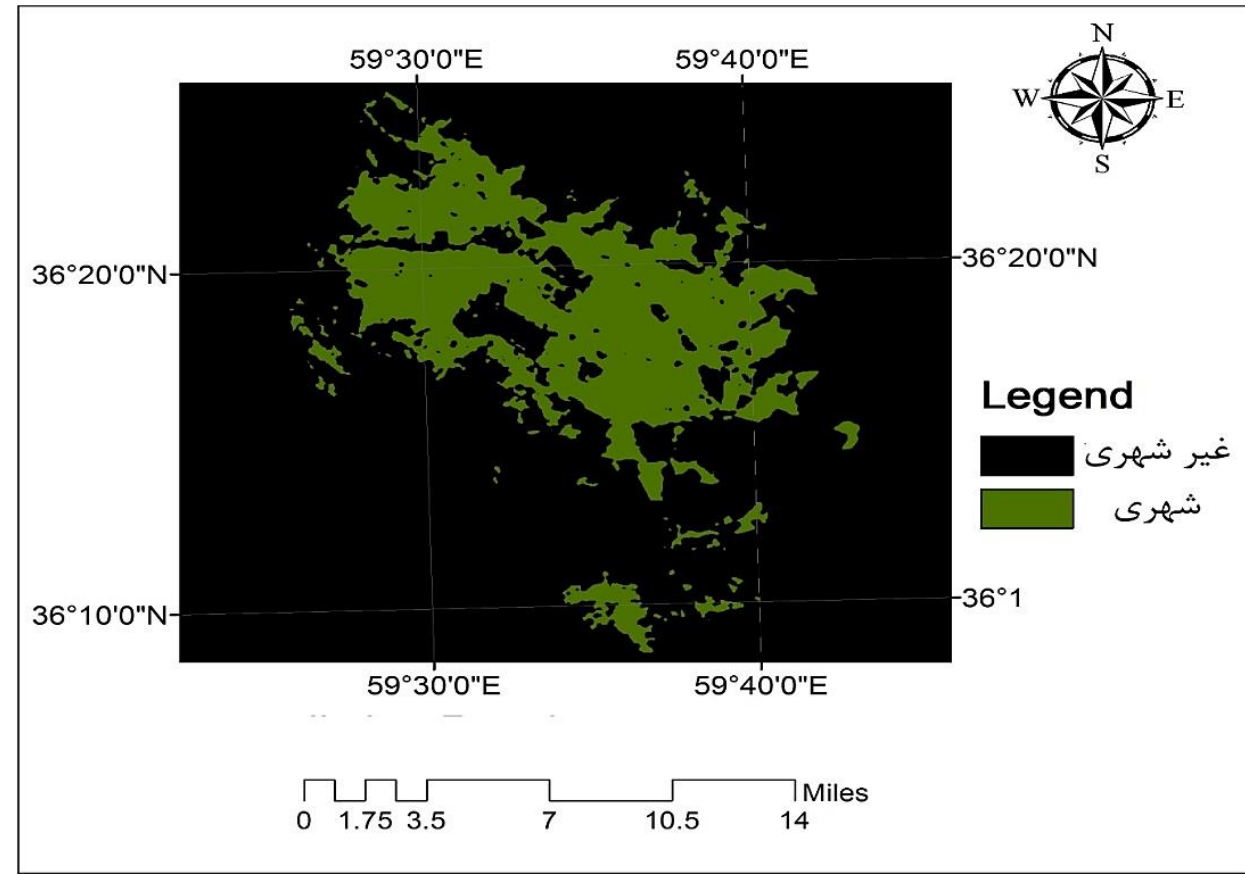

شكل ||: نقشه يِشبينى رشد شهرى براى سال ^r+r

فاكتورها با استفاده از ركرسـيون لجسـتيك وزن دهـى شدهاند. بـا برقـرارى ركرسـيون لجسـتيكى بـين نقشــهـ

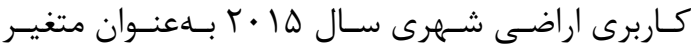

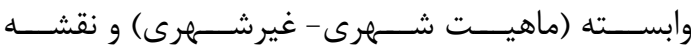
فازى سازى شده، فاكتورهاى موردنياز بــه همــراه نقشــهـ

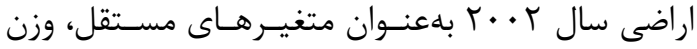

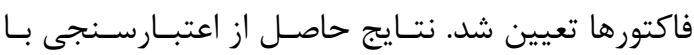

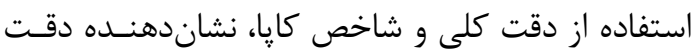

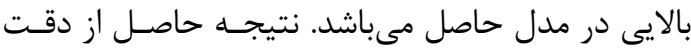

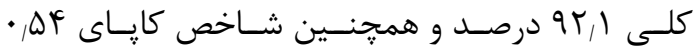

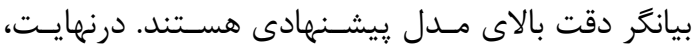

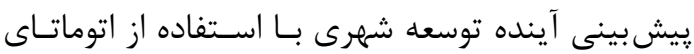

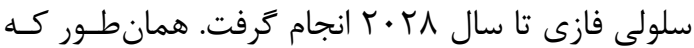
مشاهده مىشـود شـكل (T) (I) بيشـترين رشـد شـهرى جسبيده به شهر (رشد يِيوسته) در قسمت شمال شرقى و شــمالى اتفــاق افتــاده اسـتـ بـــا مقايســهـ مقـــادير محاسبهشده با واقعيت، مشاهده مىشود كه دو قسـمت
ه - بحث و نتيجهَ اتوماتاى سلولى روشى جزء بهكـل بـا سـاختارى سـاده

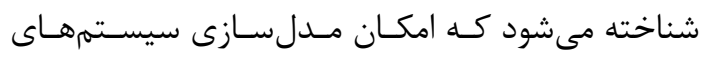
ييجِيده را به راحتى مهيا مى كند. عـلاوه بـر آن در ايسن مطالعه، سعى شده است تأثير اثرات فيزيكىى و انسـانى

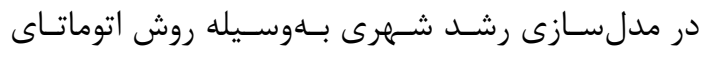
سلولى بررسى شود. از ديخر ملزومات تحقيق درزمينهى

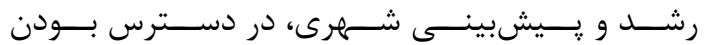

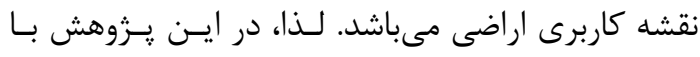

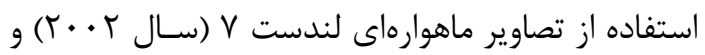

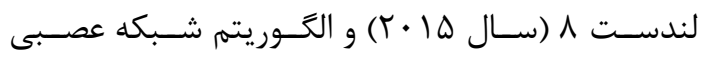
مصنوعى، نقشه تصاوير طبقهبنـدىشـده تهيـهـ گرديـد.

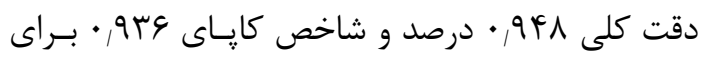

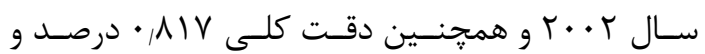

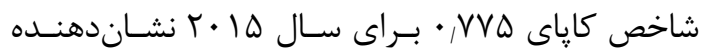

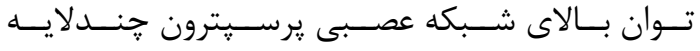

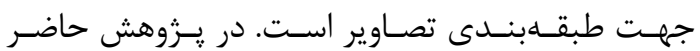


استفادهشه است. لذا در مرحله بعـدى مسىتـوان

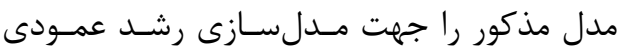

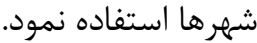

در مــدل طراحسىشـــه، خروجسى آن وضـعيت

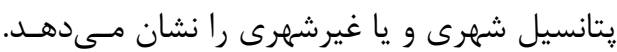
مى توان براى افزايش قابليتهاى مــدل خروجسى آن را به كلاسهـاى ديخـرى نيـز تقسـيهم نمـود.

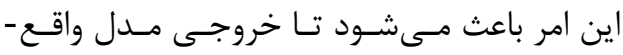

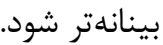

توسعه شهرى يك فرآيند فازى بوده كه بهوسـيله

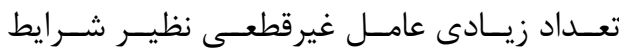

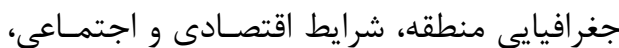

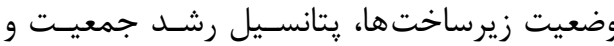

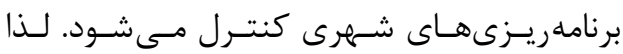

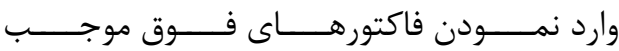
افزايش كارايى مدل و بالا رفتن دقت مى گردد. هر اين يزوهش جهت تهيه نقشه كـاربرى اراضى

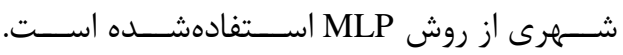
ييشنهاد مىشود كه هدف تحقيـق بـا روشهــاى إن روني طبقهبندى ديكر بر آورد و مقايسه كردد. ما بوجه به آنكه نقشـه همسـايكى در فاكتورهـاى ورودى يزوهش حاضر در نظر كرفته نشده اسـت،

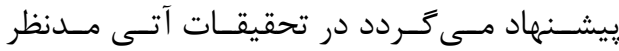

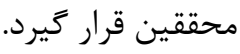

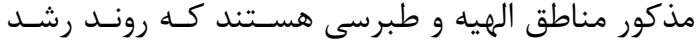
فزايندهاى خواهند داشت. طرح جديد جامع شهر مشهد براى ياسخكويى به جمعيت سـه ميليـون و هشتصـد و

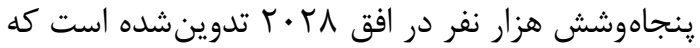

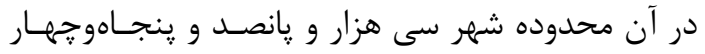

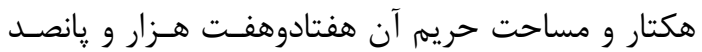

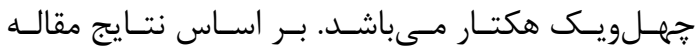

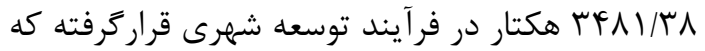

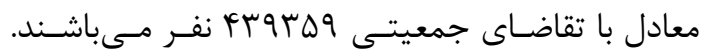

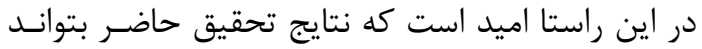

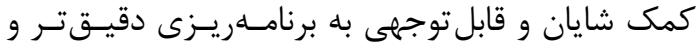

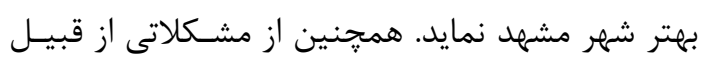
حاشيهنشينى، زاغهنشينى، وجـود محسلات نامتعـارف و

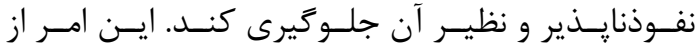

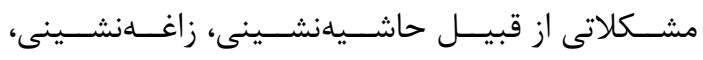

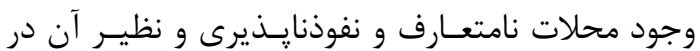
جهت نيل به توسعه پايدار جلوگيرى مىنمايد. مدل اتوماتاى سلولى بيـانشـــه در ايـن تحقيـق، ابـزار

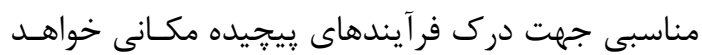

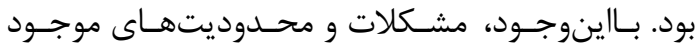

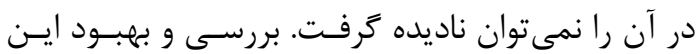

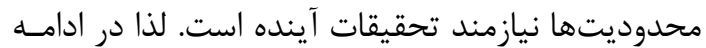
ييشنهادهايى به شرح زير ارائه مى رَردد:

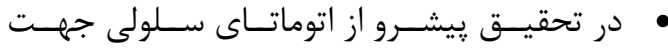

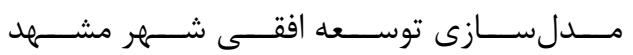




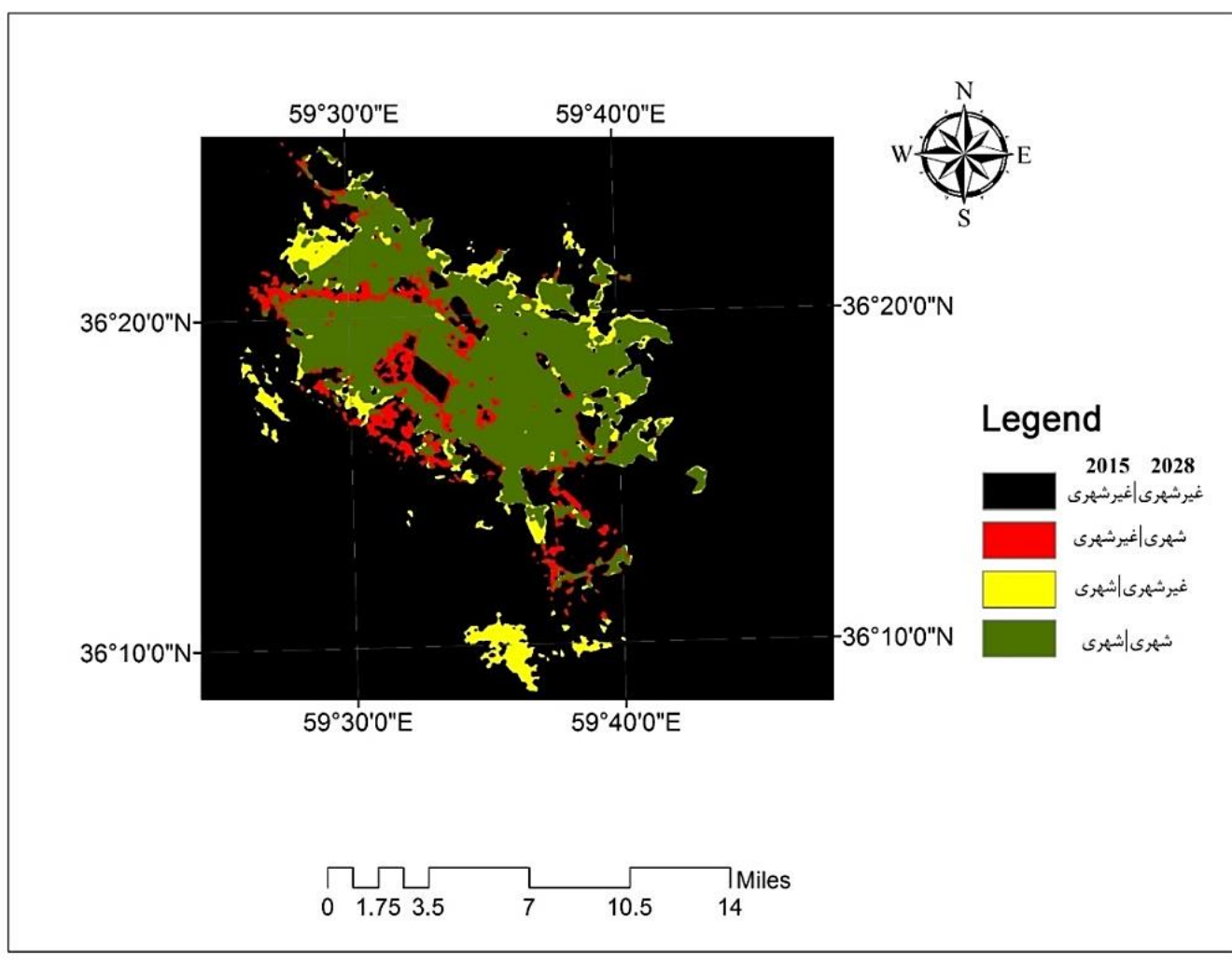

شكل rا: مقايسهاى ميانسال ها+r و پِيشبينى سال ^ץ+r

[1] World Urbanization Prospects: The 2014 Revision. Report ST/ESA/SER.A/366. New York.

https://esa.un.org/unpd/wup/Publications/Fil es/WUP2014-Report.pdf. Accessed 16 November 2016.

مركز آمار ايران هوبا. سرشمارى عمومى نفوس و [2] مسكن هوس ا, ايران: معاونت برنامهريزى و كنترل راهبردى نهاد رياست جمهورى

[3] Liu, Yaobin, Lu Dai, and Huanhuan Xiong, "Simulation of urban expansion patterns by integrating auto-logistic regression, Markov chain and cellular automata models", Journal of Environmental Planning and Management, Vol.58, pp. 1113-1136, 2015.

[4] Hossein zadeh, K, "Perspectives, Elements and Factors Affecting the Physical Development of Iranian Cities", Journal of Geography and Regional Development, Vol
6, pp 214-226. 2006

[5] Deep, S. and Saklani, A, "Urban sprawl modeling using cellular automata", The Egyptian Journal of Remote Sensing and Space Science, Vol 17, pp.179-187, 2014.

[6] Al-Ageili, Munira, Malek Mouhoub, and Joseph M. Piwowar. "Integrating remote sensing, GIS and dynamic models: Cellular automata approach for the simulation of urban growth for the city of montreal", Electrical and Computer Engineering (CCECE), 2013 26th Annual IEEE Canadian Conference on. IEEE, 2013.

[7] S. Wolfram, Cellular automata as models of complexity, 419-424, 1984.

[8] I. Sante, A. M. Garcia, D. Miranda and R. Crecente, "Cellular automata models for the simulation of real-world urban processes: A review and analysis". Landscape and Urban Planning, 96(2), 108-122, 2010. 
[9] Tobler, W.R, "Cellular geography”. In: Gale, S. Olsson, G. (Eds.), Philosophy in Geography. Reidel, Dordrecht, 1979.

[10] Wu, F. W. C, "Simulation of land development through the integration of cellular automata and multicriteria evaluation". Environment and Planning B, Planning and Design, Vol 23, pp. 103-126, 1998.

[11] Li, X. Yang, Q. and Liu, X. "Discovering and evaluating urban signatures for simulating compact development using cellular automata", Landscape and Urban Planning, Vol 86, pp. 177-186, 2008.

[12] Al-kheder, S. Wang, J. and Shan, J. "Fuzzy inference guided cellular automata urbangrowth modelling using multi-temporal satellite images", Int. J. Geogr. Inform. Sci, 22(11-12), pp. 1271-1293, 2008.

[13] Al-Ahmadi, K. See, L. Heppenstall, A. and Hogg, J. "Calibration of a fuzzy cellular automata model of urban dynamics in Saudi Arabia". e c o l ogi c a 1 com p 1 e x i t y, Vol 6, pp. 80-101, 2009.

[14] Rafiee, R. et al. "Simulating urban growth in Mashad City, Iran through the SLEUTH model (UGM) », Cities, Vol 26, pp. 19-26, 2009.

[15] Munshi, Talat, et al. "Logistic regression and cellular automata-based modelling of retail, commercial and residential development in the city of Ahmedabad, India”, Cities 39, pp 68-86, 2014.

[16] Ménard, André, and Danielle J. Marceau. "Exploration of spatial scale sensitivity in geographic cellular automata". Environment and Planning B: Planning and Design 32.5 693-714, 2005.

[17]W. Clark and P. Hosking, Statistical Methods for Geographers, New York: John Wiley \& Sons, 1986.

[18]D. Z. Sui and H. Zeng, "Modeling the dynamics of landscape structure in Asia's emerging desakota regions: a case study in Shenzhen", Landscape and urban planning, 53(1), 37-52, 2001.
[19]F. Wu, "Simulating urban encroachment on rural land with fuzzy-logic-controlled cellular automata in a geographical information system", Journal of Environmental Management, 53(4), 293308, 1998. 


\title{
Modeling and Prediction of Horizontal Urban Growth of Mashhad study region by Aggregating Cellular Automata, Fuzzy Theory, Neural Network and Logistic Regression
}

Farhad Rostami Galeh ${ }^{1}$, Marjan Ghaemi ${ }^{2}$, Rozbeh Shad ${ }^{* 3}$, Yasaman Lohrabi ${ }^{4}$

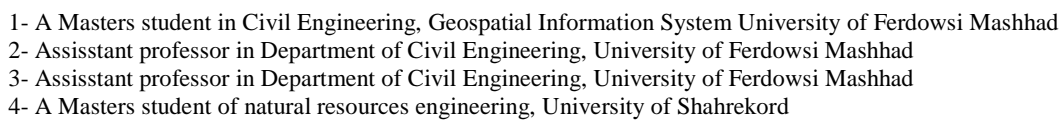

\begin{abstract}
In this paper, we try to present a simple and powerful model to forecast the urban growth of Mashhad city applying a developed Cellular Automata (CA) algorithm in Geo-spatial information System (GIS). In spite of different CA's advantages in urban growth modeling, this model faces several limitations such as inability to model the uncertainties of urban systems and working based on experimental calibration (trial and error) techniques. In the proposed method, to overcome the uncertainty problem and increase the model efficiency, the fuzzy transition rules are introduced in the modeling process. Moreover, the effective criteria are weighted using the logistic regression algorithm to remove the second restriction and then the calibration process will be applied. Therefore, the prediction process of urban growth were implemented using a suggested simple and powerful model by aggregating different methods in a logical framework. For this purpose, Landsat 8 and ETM+ satellite images (between 2002-2015) were entered into the modeling process and the horizontal urban growth of Mashhad study area were predicted for 2028. The final obtained results showed that the proposed method with the Kappa coefficient of 54.8 and the overall accuracy of $92 \%$ is more accurate than conventional CA techniques.
\end{abstract}

Key words:. Fuzzy cellular automaton, anticipating, GIS, logistic regression, multilayer perception artificial neural network 